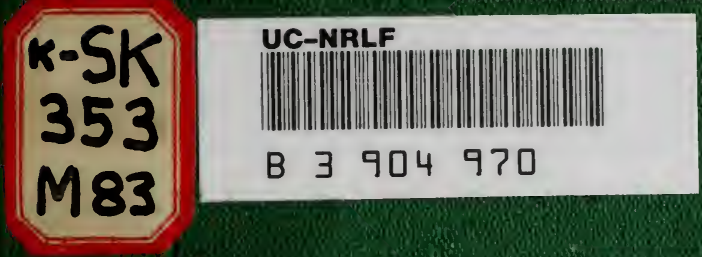




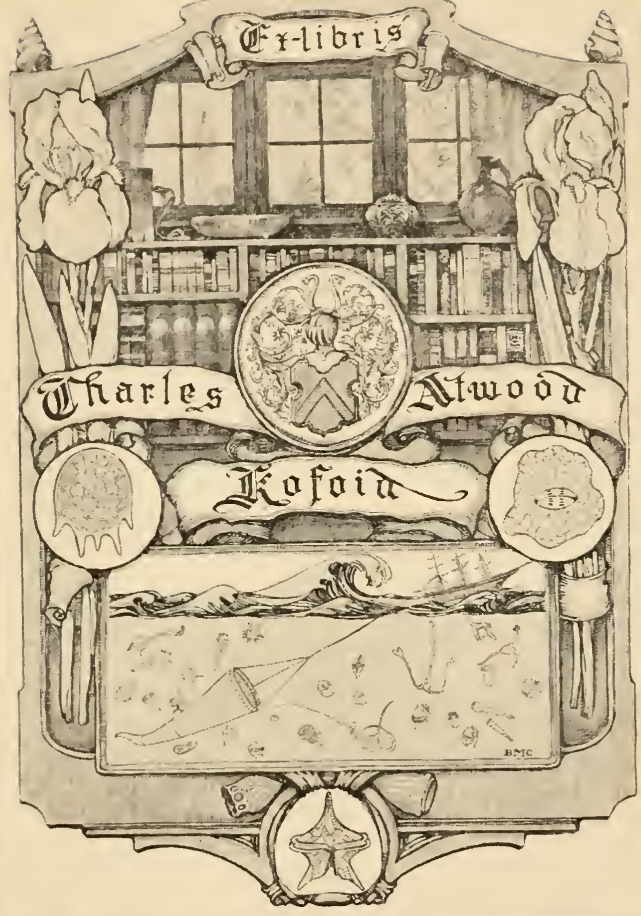




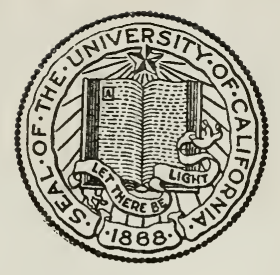

THE LIBRARY OF

\section{THE UNIVERSITY OF CALIFORNIA}

PRESENTED BY

PROF. CHARLES A. KOFOID AND MRS. PRUDENCE W. KOFOID 
11

$$
7
$$




\section{GAME AND BIRD PRESERVERS}


LONDON : PRINTED BY

SPOTTISWOODE AXD CO., NEW-STREET SQCARE

ASD PARLIAMENT STREET 


\title{
GAME PRESERVERS AND
}

\section{BIRD PRESERVERS}

\author{
WHICH ARE OUR FRIENDS?
}

BY

\section{GEORGE FRANCIS MORANT}

LATE CAPTAIN 12TH ROYAL LANCERS : MAJOR THE CAPE MOUNTED IIFLEMLX

LONDON

L O N G M A S, GRE N, A N D C O. 1875 



\section{SIR THOMAS MILLES RIDDELI, BART.}

OF STRONTIAN, ARGYLLSHIRE

LATIE OF THE TTH DRAGOON GLARDS

A KIND FRIEND AND A GOOD NEIGHBOUR

The Gathor dedicates this little \$aok

IY REMEMBRANCE OF PLEASANT YEARS SPENT AMONG CHARMIYG

SCENES WITH WHICH SIR T. M. RIDDELL HAS BEEY

FAMILIAR FROH CHILDHOOD

Juxior. Uxited SERvice Club, Londox

June 17,1875 



\section{PREFACE.}

In whatever part of the world the author has found himself, Birds have furnished an endless source of amusement to him.

It was therefore with great pleasure that he heard that the subject of their preservation was to be brought before Parliament, and he read with interest the Report of the Evidence given before the Select Committee appointed in 1873, to enquire into the advisability of extending the protection of a close season to certain wild birds.

But no one can read this evidence without noticing how little the subject of the preserva- 
tion of birds is understood, nor, we should think, without wondering whether some of the naturalists, who appear as witnesses, are not wolves in sheep's clothing, who, far from really wishing to see all beautiful and useful birds protected by law and increasing in numbers, care little if they are nearly exterminated, provided they can carry out certain theories of their own.

The Report of the proceedings of this Committee is printed in a folio volume, and in every case in this little book, where the author has quoted the opinion of any of the witnesses, he has cited the very words used in the printed Report.

While we know that the rent which our estates return, and the pleasure of living on them to many people, depend on the numbers of certain birds, and the productiveness of our farms and gardens on the presence of others, the inhabitants even of civilised countries, with 
few exceptions, have, up to the present time, killed their birds, or allowed them to be killed in their breeding season; just as the Indian and Kaffir boys who are idling about the villages in Asia and Africa kill all they can, on every day in the year; and it seems to be only now dawning upon some of us that this is not much more rational than to allow our cattle and sheep to be treated in the same manner.

The author's own opinions are formed from pursuing and collecting birds over a great part of India, and for some years in South Africa. $\mathrm{He}$ has resided of late years in the wildest part of the Highlands of Scotland; and having had the sole right of shooting over more than 100 square miles of country, he has, with the greatest satisfaction, watched the increase in return for the protection bestowed upon them, of all the birds whose presence upon our property adds most to its value.

If this little book should induce a single 
reader, who now neglects his birds, to extend to them this protection which they so much require, the author will be well repaid for the trouble of writing it.

The Jenior United Service Cleb, London : June 1875. 


\section{CONTENTS.}

CHAPTER

PAGE

I. Oy Birds generally, ANd the Report of the Commttee . . . . . 1

II. The Balance of Nature . . . . $1: 3$

III. The Grouse Disease . . . . 25

IV. Birds of Prey . . . . . . 38

V. The Eagle, the Buzzard, and the HenHARrier . . . . . . 51

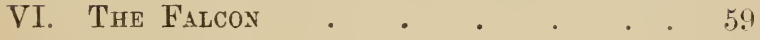

VII. The Sparrow-Hawk, the Merlin, the Kestrel, and the Owl . . . 76

VIII. The Raven, the Crow, the Magpie, the JAY, AND THE ROOK . . . . 84 
xii CONTENTS.

CHAPTER

IX. The Fox

X. The Polecat, the Stoat, the Weasel, and the Hedgehog . . . . 108

XI. The Rat and the Cat . . . . 117

XII. The Grouse . . . . . . 129

XIII. The Black Grouse and the Partridge. 144. XIV. The Pheasant . . . . . 158 XV. Pheasant Rearing. . . . . . 171 XVI. The Wood-Praeon and Hodse-Sparrow 185 XVIJ. How to Pbeserve all Birds . . 193 


\section{GAME PRESERVERS AND}

\section{BIRD PRESERVERS.}

\section{CHAPTER I.}

ON BIRDS GENERALLY AND THE REPORT OF THE CONLITTEE.

WHEN we find nation after nation. making laws for the protection of wild birds, we may be sure that there is a growing feeling that this is absolutely necessary. A very cursory glance over the mass of evidence given before the Select Committee appointed. in 1873 to enquire into the advisability of extending the protection of a close season to certain wild birds not included in the 


\section{GAME PRESERVERS AND BIRD PRESERVERS.}

Wild Birds Preservation Act of 1872 will show how useful these creatures are to man, and this evidence may be considered a summary of all that is known about birds up to the present time.

If the subject were more generally understood, every owner or occupier of land would be a bird preserver, and consequently a game preserver, and no laws for their protection would be necessary.

It is no exaggeration to state that if birds could be exterminated our fields and gardens would in a few years scarcely repay the expense of cultivation, or, as Mr. Cordeaux expresses it, ' farming would be practically impossible without birds,' while the extermination of our game birds would cause a loss of an income of many thousands a year to our landowners, and a loss of hundreds of tons of delicious food to the general public.

Leaving out of the question for the moment the Grallatores and Natatores, all harmless and 
beautiful, and many of them excellent as food for man, and the few birds which are cannibals and eat each other, every mouthful which a bird eats may almost be said to be either an insect or a sced, so when we have protected the seeds which we value they are incessantly destroying either a farmer's and gardener's live enemies or the weeds which clog his ground.

Few people have owned the smallest garden without finding out the cruel damage which many sorts of grubs and insects commit. Many of the gentlemen who appear before this Committee give most interesting information about insects, their depredations, their powers of reproduction, \&c. Mr. Groome Napier tells us, 'Some, such as the white ant, lay 40,000,000 eggs, laying them at the rate of 60 a minute. Alegrodes proletella lays 200,000, a species of mutilla S0,000 a day. The queen of the hive bee is capable of laying 50,000 in a season; the female wasp 30,000 ; various species of coccus 
4 GAME PRESERVERS AND BIRD PRESERVERS.

from 2,000 to 4,000 ; some moths 1,000. Most insects have two generations in a year, some have 20 , while others take seven years from the time the egg is laid until their natural death in a perfect state.'

'The beetles (coleoptera) are immensely numerous as regards species. They live from three to four years in the larvæ state. The first year they do not do a great amount of damage. The second year they attack the roots of all plants within their reach; they often ruin the crops of corn, lucerne, \&c., on which man depends for food. In a field of 29 acres in France, 43,200 larvæ were found; quite sufficient to destroy the entire crop during the season.'

Mr. Muller gives the names of 28 insects that are always found attacking the apple-tree alone.

Mr. Harting quotes from a French work, that ' out of 504 grains of rape only 2.96 were healthy ; the remainder were eaten or destroyed 
by insects. There was a consequent loss in oil of 32.8 per cent. In a harvest which produced 180l., it was necessary to calculate a loss of 108l., which, could it have been avoided, would have produced 288l.'

Mr. Warner states, 'Some years ago the damage done to the seed growing by small birds induced my father to have all the birds destroyed that he could. The result was that we had no leaves on the gooseberry trees at all, and we lost all our crops of fruit entirely ; and many similar instances are given.

The insects that are vegetable feeders are partly kept in check by other insects which prey upon them, and it is an interesting fact that these insects are not eaten by birds. This is mentioned by the Rev. G. J. Wood. There is an ichneumon fly that lays its egg on the body of a live caterpillar, and when it hatches it certainly eats him to death. It is to be hoped the unfortunate caterpillar does not know the fate that awaits him. He is much in 
6 GAME PRESERTERS AND BIRD PRESERTERS.

the position of a human being afflicted with in curable cancer.

But it is on the bircls that we must mostly depend for help, and how much they help may be imagined when the Rev. F. O. Morris tells us 'that a rook requires, at a very low estimate, one pound of food a week, and that of this nine-tenths are insects and worms; so that in one season 100 rooks will destroy 4,780 lbs. of insects and larvæ. On this calculation a rookery of 10,000 rooks will consume in one year 468,000 lbs. or 209 tons of worms, insects, and their larræ.'

Mr. Groome Napier states that one of the most destructive grubs is the larva of the cockchafer, and that the rook and starling make it a speciality to eat them; while Mr. F. Bond took out of the crop of a cock pheasant 444 grubs of the crane $\mathrm{fly}$, out of the crop of a partridge a handful of agrotis segetum, the turnip moth, and teaspoonfuls of wire worms out of larks, plovers, starlings, and rooks. 
BIRDS AND REPORT OF COMMITTEE.

The last-named gentleman gives two instances of crops being saved by starlings.

As regards the seed-eating birds, these generally feed their young upon insects, while if we reflect that every seed which they eat, except those which man actually sows himself in his fields and gardens, will probably grow up as a weed, their services in destroying these are enormous. We have then only to protect our seed-beds for a few days after sowing, and our fruits and corn crops for a few weeks when ripe before we gather them; and these birds are equally our benefactors all the rest of the year. Yet we very generally destroy them because they cannot resist our delicious fruits and the golden harvest which we spread before them so temptingly. Surely this is unworthy of the nineteenth century, and after all that we now know of their habits. Our corn crops must be protected by bird-boys, and the expense of doing this effectually should not be grudged. The poor little urchin we so often see, not so very 


\section{S GAME IRESERVERS AND BIRD PRESERVERS.}

much larger than an unusually fine cock-sparrow himself, furnished with a saucepan and stones to rattle together, is not sufficient. Lads must be employed old enough to be entrusted with guns, and they must shoot some of the birds at this time of the year, as they soon become cunning enough to disregard a noise which experience teaches them is 'Vox et proterea nihil.'

Our very large gardens can only be protected in the same way. Mr. Meyers tells the Committee he has thirty or forty acres of gooseberries and strawberries alone. He adopts this plan, and protects all bircls as much as possible during the rest of the year. In smaller gardens netting is most effectually used. String netting is sold now at $\frac{1}{2} d$. the yard, and even wire netting is now very cheap. We grudge no expense to fence our gardens securely against the beasts of the field, and need not grudge a small outlay to make them secure at certain times against the fowls of the air. With our seed-beds protected by wire guards, which can be moved from bed to 
bed as required, and our strawberries, gooseberries, \&c., protected by nets stretched orer neat wooden frames, we could welcome every bird which would visit our garden, certain that whether he eat seed or insect he was doing us good service. In fact, we may lay it down as a rule that the only bird that really injures man is the bird which kills another bird.

The evidence about the beautiful ' bullfinch' is most conflicting. Some gentlemen maintain that he eats the buds and destroys all the fruit; others that he only picks the bud for the sake of the grub which would otherwise destroy it. If a few gooseberry bushes were carefully netted down during the three weeks in which he is seen picking the buds, and their produce accurately compared with that of the bushes to which he had access, this question would be set at rest. An established fact is worth any amount of theory. If he is in pursuit of the grub the remedy is often as bad as the disease. Four years in succession he stripped our gooseberry 
bushes of their buds, and we had not a single ripe gooseberry. We would protect the trees, not destroy this pretty little creature.

No one can read the proceedings of this Committee without being struck with the patience with which, without partiality, farour, or affection, they elicited all possible information from the twenty-nine gentlemen who appeared before them.

Or we should think without agreeing with their report, and considering it highly desirable,

1. That the protection of certain wild birds named in the schedule of the Wild Birds Protection Act be continued.

2. That all other wild birds be protected from March 15 to August 1, provided that owners or occupiers of lands and persons deputed by them have permission to destroy such birds on lands owned or occupied by them.

But the public are left to find out for themselves how best to carry out this recommendation -whether to protect all these birds it is neces- 
sary for man to kill any wild creatures himself or not; and when we see how widely so many gentlemen differ in their opinions we cannot help feeling how little practical natural history is understood.

It is not the number of inches which a bird measures from the tip of its beak to the tip of its tail which we want to know, nor even the colour of its eggs, but whether its presence on our land is an advantage to us or not.

Many naturalists tell this Committee that our gamekeepers are ignorant and cruel, and do more harm than good.

Then quite a number believe in a state of things called the 'Balance of Nature,' with which man should never interfere.

We will examine this view of the subject in the next chapter.

Mr. A. Ellis would seem to belong to this school. On 1,400 acres he allows ' nothing to be destroyed except the grey rat.' These gentlemen all wait until the birds and beasts 
12 GAME PRESERVERS AND BIRD PRESERVERS.

of prey have fed, and then humbly accept as man's portion the crumbs which fall from these creatures' tables.

Some gentlemen give the Committee their theory of the cause of that grievous calamity, the grouse disease. Perhaps this will interest some people.

Then all our birds and beasts of prey are mentioned, and all our game birds, and some interesting information is given about the wood-pigeon and house-sparrow. 


\section{CHAPTER II.}

\section{THE BALANCE OF NATURE.}

THE part which beasts and birds of prey had to play in the scheme of creation was clearly to reduce the numbers of the creatures they preyed upon; and though at first this may seem a cruel arrangement, it is difficult to see how any other could have been invented, unless each bird and animal had been created to die suddenly after a certain time, like an eight-day clock which has run down. Most animals' powers of reproduction are so great, evidently with a view of directly or indirectly affording food to man, that but for some such check before the appearance of man upon the scene, they would have crowded each other cut, and have died miserably of starvation. 
14 GAME PRESERVERS AND BIRD PRESERVERS.

But when man appears and assumes his dominion over the beasts of the field and the forvls of the air, the mission of these murderers and cannibals is at an end. They disappear before him all over the world, and it is worthy of remark that all the creatures which man feeds upon increase and prosper in a wonderful manner; the protection he gives them by destroying their natural enemies so far out-balancing the injury he inflicts upon them by killing them himself when he requires them.

The sheep was doubtless a rare animal before he was used as food by man, and only maintained his existence because his warm woollen coat enabled him to live at an altitude where but few beasts of prey cared to follow him, while now he is one of the most numerous and one of the happiest animals in the world. Since sheep-farming has become general at the Cape of Good Hope, the jackal, which was so plentiful in 1850 that the 7 th Dragoon Guards imported a pack of English 
fox-hounds to hunt them, and gave sport that is still remembered with pleasure, has entirely disappeared. During a residence there of some years we but once even heard one. The first thing that the farmer does in every part of the world, if he wishes. his sheep to increase, is to kill the animals that would kill them in the breeding season; and the first thing that gentlemen have been in the habit of doing who wished to see beautiful and useful birds increase has been to take care that no bird or beast should molest them during their breeding season. The twentynine gentlemen who came to give eridence before this Committee all agree that our birds ought to have a close time when they should be protected by law, but several of these witnesses, the Rev. Mr. F. O. Morris, the Rev. Mr. Tristram, Mr. R. Gray, all wellknown naturalists, and others, followers of a school of which the late Mr. Waterton may be said to have been the founder, are most 
16 GANE PRESERVERS AND BIRD PRESERVERS.

anxious to protect at the same time the very bircls which will inevitably destroy the harmless birds in countless thousands, and during their breeding season-to go back to the state of things that existed before man interfered,-and they maintain that while all his success and his very existence depend on his having interfered in the animal and vegetable world, in his having destroyed creatures that were noxious to him, and having protected creatures that were useful to him, in the bird world a state of things exists called the balance of nature, with which he ought never to interfere. Mr. WV. C. Angus thinks, 'as a rule, that Nature, if left to herself, will fairly preserve the balance.' But this will be the balance that existed before man appeared. Is it likely to be what is now required?

As a single instance that the balance which Nature establishes is not the balance among birds which is useful to man, any more than among beasts, we may mention that she loves 
the worthless hoodie crow much more than she loves the grouse which fetches $5 s$. a brace in our markets. In 1864, on one large estate nearly 400 crows were killed, and at that time there were hardly 100 grouse on the whole property. In 1873 nearly 900 grouse were killed, and about 40 crows. Her arrangement in Scotland of lots of crows and hardly any grouse is no more profitable to Man than her South African arrangement before referred to, when jackals were howling in every wood, and the muttongiving, wool-bearing sheep were represented by a few creatures whose tails were heavier than their fleeces.

Mr. Scott Skirving states 'that no bird on earth would be a nuisance if man had not interfered with them.'

Then why should the wolf or any other animal? But it is difficult to see how man is to exist or to exercise his dominion over living creatures without interfering; or, as Dr. Günther expresses it, 'Man's task is to interfere with the 
18 GAME PRESERVERS AND BIRD PRESERVERS.

natural condition of things so as to turn everything to his advantage.' The whole of this last-named gentleman's evidence is most interesting, and he takes a very wide view of the subject.

Even Lord Lilford, who is a sportsman, seems to believe in this balance in nature, and states, 'My view is if we allowed the hawks to increase and take their share of the small birds, we should get about the right balance.'

But this is in answer to a question about the sparrows. We should think that a gentleman who buys a fine Highland property, and then leaves the hawks to decide what number of grouse should breed upon it in every season, does not act much more wisely than a farmer would, who on settling in Australia allowed the wild dogs to decide what number of ewes should breed on his land every year.

But how is it possible that these gentlemen, who know something of natural history, and who advocate a close time for every bird, can 
fail to see that what they would get would be a close time for no bird, except, since ' hawks will not pick out hawks' eyes,' for the five or six sorts of birds of prey which still infest this country? By what stretch of the imagination can the grouse, which so gallantly ran the gauntlet of our guns in the autumn, be said to enjoy a close time in the spring, when they are being killed and torn to pieces every day from March to August by the peregrine falcon? Or how can this be said of the birds whose songs delight us, and who do us such good service in our gardens, while we allow them to be carried off before our eyes every day? But the more carefully we have read all this mass of evidence, the more clear it seems to us that at the present time the game preserver is the only bird preserver, the only real friend all our birds have; and any lady who resides on a really well preserved estate may rest assured that ten larks, blackbirds, and thrushes are singing to her every summer evening as she walks through the fields and woods, 
20 GAME PRESERVERS AND BIRD PRESERVERS.

for every one that she would hear were the owner of this property to listen to the advice of certain naturalists and send away his cruel keepers, leaving the balance in nature to adjust itself.

It is a great mistake to imagine that man drives birds away by cultivating the surface of the earth. He feeds hundreds in feeding himself, and they are infinitely more numerous in our gardens and on our farms than in the primeval forest where his foot never penetrates, or on the great fertile plains where he has not yet turned the earth.

On a stormy November day in the Highlands of Scotland, after walking for hours on uncultivated ground and scarcely seeing a bird except a few black game or an occasional woodcock or snipe, on coming to a stubble field, should it be only of six or eight acres in extent, we always find it alive with birds of all sorts; wild ducks, curlews, oyster catchers, gulls, rooks, crows, and clouds of small birds will have assembled from all the country round. 
As Sir D. Wedderburn states, if we wish birds to increase, 'improved conditions of existence are even more important than protection.' It is when Man supplies both that he obtains really great results, and in no part of the world with which we are acquainted can any bird or beast, except the Raptores and Carnivora, be said to enjoy a close time for breeding unless Man interferes and procures for them this priceless boon. But it is not by making laws which bind only his fellow-men that he can do this. Man's non-interference was Mr. Waterton's plan, and it is to say ' peace where there is no peace.' We can see the working of this system any day, not on a little park of 300 acres, but on thousands of miles of country in Asia and Africa, and until quite lately on hundreds of square miles in the Highlands of Scotland, where population is very scanty and where no one thought of wasting a charge of powder by shooting a bird, or of spending his time in looking for birds' nests. 
22 GAME PRESERVERS AND BIRD PRESERTERS.

We read somewhere that a member of one of the French Assemblies once made a very long speech in favour of the abolition of capital punishment, dwelling long on its being the sacred duty of all men to respect human life. He was answered in a few words by another member, who agreed with all he had said about its being all men's duty to respect human life, but he suggested, 'Que messieurs les assassins commencent.' Man must lay down the law and enforce it, that the bird or beast which sheds birds' blood, in the pleasant spring and summer months, by man must his blood be shed; or the beautiful and useful birds which all these gentlemen, whose evidence we have been reading, appear so anxious to protect cannot possibly enjoy the close time they would give them by law from March 15 to August 1.

Many country gentlemen have for a long time been in the habit of employing men to protect useful birds in their breeding seasons; but so little is what these men do, understood, that 
we find one gentleman telling this Committee, ' Keepers think everything but game is to be murdered.' Another in almost the same words : 'An average gamekeeper kills everything as vermin except what is in the game list;' while Mr. Stevenson actually gravely tells the Committee that ' a Norfolk gamekeeper told a friend of his he shoots the nightingales and takes their eggs because they sing so loud that they keep his pheasants awake at night.' We cannot help fancying that this gamekeeper was amusing himself a little at the expense of a gentleman who did not know much about pheasants, and he must be not a little surprised to see his joke given as evidence to a Committee of the House of Commons.

We propose to show what the creatures are which keepers destroy, and why they destroy them. So far from ' murdering everything but game,' it will be found that the sorts of birds they kill can be counted on their fingers, and their numbers in scores, while the sorts of birds 
24 GAME PRESERVERS AND BIRD PRESERVERS.

they protect are counted by hundreds, and their numbers by tens of thousands.

They simply see that the very recommendation of this Committee is carried out. This wild beast, which with some skill and cunning they have at last trapped, was breaking the law ; and that wild bird which they have traced to her mountain home, and watched for weeks, was offending against it every day. In killing these creatures they have no more done a cruel or barbarous action than their ancestors did when they killed wolves. 


\section{CHAPIER III.}

THE GROUSE DISEASE.

THE motive which is inducing some landowners to reintroduce the cruel rule of the birds of prey over their fine estates is to be found in the theory which certain gentlemen have formed of the cause of that national misfortune "the grouse disease.' This theory is that our breed of grouse has become degenerate, weak, and sickly, and that at last an epidemic has broken out among them which is carrying them all off, because for some years man has been in the habit of reducing their number by killing them himself for a short time in the autumn, instead of allowing them to be torn to pieces by their natural enemies all the year round. In the first place, to reason by analogy, will these naturalists 
26 GANE PRESERVERS AND BIRD PRESERVERS.

explain why, while we have seen the partridge, wood-pigeon, starling, and house-sparrow, increase in still greater numbers, and for the same reason-the destruction of the creatures which prey upon them-and yet show not the slightest signs of degeneration, our own beautiful British game bird, the grouse, can only be kept in health by being subjected to this cruel ordeal? As Dr. Giinther expresses it in answer to a question by the Hon. A Herbert, "This is an hypothesis easily rebutted by other evidence and not borne out by any other facts observed in the animal kingdom.' Then Mr. Tegetmeier has published it as his opinion that the cure for the grouse disease is to preserve our birds of prey, ' as they always kill the weak birds and leave the strongest to breed.'

We believe that a more erroneous idea was never promulgated, and we write from living among the grouse and their enemies all the year round, not from visiting the moors for a few weeks in the autumn. 
Weakness in the grouse is not in any way necessary to enable the hawk to kill him, nor, ninety-nine times out of one hundred, is the greatest amount of health and strength of the slightest avail to save him from his pursuer.

The finest cock grouse in all Scotland has no more chance of escape when he once rises from the heather before the wild peregrine falcon than an unfortunate rabbit would have if Master M'Grath were slipped after him in the middle of Salisbury Plain.

We have seen even the little merlin hawk overtake in fair flight and kill an unusually fine old grouse in the month of February; and a grouse came by pursued by the sparrowhawk in the month of January, and though by shouting and throwing our hats at the hawk he was compelled to make a wide detour, he caught and killed his quarry before our eyes; and in a single walk straight through the hill in the spring on one day we picked up the remains of five grouse all killed by falcons within a 
week, and in a country where they are rather larger than usual and disease is unknown.

It would be as reasonable in our opinion to fire a mitrailleuse down Piccadilly once a week with the idea of improving the stamina of the London population by destroying sickly children and incurable invalids as to allow the falcon to breed with the idea that he will kill the sickly grouse only. And the simile holds good still further, for as these sickly people would be likely to be confined to their houses and thus to escape the murderous discharge, so the sickly grouse, where they exist, are cowering in the tall heather afraid to face the open, and are the last birds that will ever rise before a falcon.

But Mr. R. Gray argues that immense numbers of grouse are every season wounded and drag on a miserable eristence, but that they all actually breed next year unless destroyed by birds of prey, and rear a sickly brood; and that this is the cause of the so-called grouse 
disease, for he adds rather naïvely ' he can see no other way of accounting for it.'

But this is not much more logical than the gamekeeper's argument, who told the Rev. Mr. Tristram that 'he was sure the cuckoos iurned. into hawks in the winter, for if not what became of them?' and it does not seem to strike Mr. Gray that if his argument is sound we should have had a 'partridge disease' also long ago.

A wounded bird, in our opinion, invariably either dies, generally in a few hours, certainly within a few days, or perfectly recovers. We do not allude to such an injury as a broken leg. The loss of a leg is a serious affair to a pheasant, who has to scratch to a certain extent for his living, but not of much consequence to a grouse. But the law detur fortiori steps in, and either bjrd has but little chance of obtaining a mate. $\mathrm{He}$ is hunted away by the other males, and must retire as fast as his one leg will carry him.

Even among men after our wars, though we see many whose constitutions are shattered 
30 GAME PRESERVERS AND BIRD PRESERVERS.

by disease, we see none who survive so injured by wounds as to be likely to give birth to sickly children.

Can we fancy a grouse telling his mate on a spring morning, 'My dear, I feel very poorly to-day; that No. 5 in my spine is troubling me dreadfully'? It would remind one of the story the old Brighton boatman told the schoolboys of the dreadful battles he used to fight when he was a smuggler, as narrated in 'Punch'-how on one occasion, 'he received three balls in his stomach and two in his head, and he felt them still sometimes in the winter, that he did.'

Our sickly poultry do not lay, and we do not believe sickly grouse do either, though they may be smitten by disease after they have paired. Let anyone creep near a pair of grouse in the spring; he will find the cock the picture of health, as he walks along with his impertinent jerky swagger. He only wants a hat and feather well on one side of his 
head and a sword by his side, and he is the beau ideal of a gay cavalier. And no English lady looks fresher or comes down to breakfast more neatly dressed than the hen, until her feathers get ruffled for want of time to attend to her toilet, and she spoils her tail by sitting too long in one position. But the Rev. H. B. Tristram has noticed that when a hawk pursues a flock of birds he always strikes the hindermost, and of course this is the weakest. We do not agree to this, because birds are so even in their powers of flight that in the short distance that a hawk follows them, this hindermost bird would be simply the one which sprang from the heather some twenty yards nearer to the hawk, and he is never able to regain his lost advantage. Mr. Tristram does not tell us, however, that for six months out of the twelve it will be a pair of grouse and not a flock which will rise before the falcon; or if he has noticed in this case that it is always the hen which he kills. Whichever he kills, it is 
32 GAME PRESERVERS AND BIRD PRESERVERS.

clear there will be a pack the less on the ground in the autumn.

Surely any deterioration in a breed of birds, before showing itself in the form of an epidemic, would show itself in a' steady decrease in their size and weight, their powers of flight, and in the number of eggs which they would lay each season. We never heard that this was observed before the outbreak of the disease.

But we seem to have a very clear clue to the reason why, of all birds in the world, the grouse is the one most likely to be attacked by some disease. Plenty of gentlemen well qualified to form an opinion have noticed this. It is found in the fact that while all other birds feed on a variety of substances, the grouse feed nearly entirely on heather. And in the same way that the Irish population when they depended entirely on the potato sickened and died as soon as the potato disease appeared, so when the heather is seriously 
injured by frost, the grouse can hardly escape sickness where they exist in considerable numbers. In a paper published in that useful book, 'The Transactions of the Highland Society,' the author had taken the trouble to trace the line of the grouse disease, and he never found it within ten miles of the west coast. Now the influence of the Gulf Stream is supposed to extend at least ten miles inland, and as far as this is felt the heather is never seriously injured by frost. But some people will say, why did not the disease show itself years ago? We believe because, when grouse were scarce, the few that were allowed to live through the winter could always find enough wholesome food. However bad the potato disease was, half-a-dozen Irishmen could have always picked out sound potatoes in sufficient quantity to keep them alive where a hundred mist have starved. If our grouse are to exist in the numbers which we like to see in the autumn, they must have something 
34 GAME PRESERVERS AND BIRD PRESERVERS.

else to depend upon in severe winters besides the wild frost-bitten heather. It is by feeding them highly, not by getting them destroyed by birds of prey, that we shall preserve them in health through the winter, and in a fit state to rear large and healthy broods in the spring.

We have seen the wood-pigeon increase in countless thousands because he can obtain in winter food which his ancestors never tasted.

We must educate our grouse to a more liberal diet in this nineteenth century. They will eat corn greedily when they can get it, which is only for a little while in the autumn and in a few places. Te have shot grouse both on the Lammermuir Hills and in Ireland, coming regularly to the stubbles every evening in the end of October, when we wanted some and they could not be approached in any. other way. The black grouse come regularly to our corn-fields, but with them it is an acquired taste. In the Austrian Tyrol, where the tail 
of the blackcock forms the favourite ornament for the peasants' hats, the foresters told us they never visit the corn-fields, and could scarcely believe that they would eat corn. There is hardly a moor in Scotland where a few acres could not be cultivated, or where grouse do not already find their way to our fields to pick up the wretched pittance we leave them. Our Highland proprietors must not grudge a little expense for the beautiful birds whose presence on their lands brings them in such large rentals. The crop should be left on purpose for them in certain small fields. They would visit these as long as a grain of corn was to be picked up, and grain should be put down regularly with a liberal hand if the weather become severe. What is even $30 l$. or $40 l$. spent in corn compared to a shooting rental of $500 l$. per annum? and no one grudges the food the breeding stock of pheasants eat in the winter. We may be wrong, but we feel convinced this plan would do far more towards 
36 GAME PRESERVERS AND BIRD PRESERVERS.

keeping grouse in health than handing them over, through the length and breadth of bonny Scotland, to the cruel surgical operations which Dr. Falco Peregrinus is only too anxious to perform on them all the year round.

Yet grouse do constantly pass through an ordeal which none but those blessed with the very strongest constitutions can stand. They are reared at a height above the level of the sea, and often in weather through which no other young game birds (except, of course, their first cousin the ptarmigan) could live. When the pelting, pitiless rain sets in, and the thermometer falls almost to freezing-point, then it is that the weakly chicks die. Those which survive are those possessing most vital energy, and these are often scarcely half the brood.

Were an old cock grouse with a constitution shattered by many wounds, almost as full of spent shot as a pudding is of currants, to pair with an interesting young hen who had suffered from chronic liver complaint all her 
life, and to succeed in hatching a sickly brood, they would inevitably succumb to the first twenty-four hours of this weather. They would not live long enough to grow wing feathers, and they would never fly before a hawk at all. If gentlemen's moors are too crowded with grouse, or if they have diseased birds on their grounds, let them send the keepers out to shoot them even in the winter months. If they leave their numbers to be reduced by the falcon, it is the strong bold birds which he will kill, and not the weakly ones, as Dr. Günther tells the Committee. 


\section{CHAPTER IV.}

\section{BIRDS OF PREY.}

BIRDS OF PREY have become so nearly extinct lately that most people's idea of what hawks do, is derived from what they see or hear about tame hawks or from watching the kestrel hovering over a field mouse. But in the Western Highlands they are still numerous, and here, the gentlemen who think 'they add a beautiful feature to human life,' and that 'they add to the picturesque in nature,' are likely for some time to come to be gratified by seeing a poor bird full of life and happiness struck lifeless on a bright May morning, or carried screaming off while his poor mate even ventures to flutter with helpless cries to his 
rescue. For ourselves we would sooner look on at a Spanish bull-fight; but the knowledge that for every time this tragedy is seen it is performed unseen five hundred times may be a gratification to some people. The terror which the mere appearance of these birds causes to the harmless birds they prey upon is but little understood; but surely no tales of 'old bogie' invented by foolish nurses to frighten children exceed the reality in this case, and we can fancy a partridge quieting a refractory young one by telling him that the hawk should have him.

Goldsmith, in his 'Animated Nature,' tells us, "Whenever they appear in the cultivated plain or the warbling grove it is only for the purposes of depredation, and they are gloomy intruders on the general joy of the landscape. They spread terror wherever they approach, all that variety of music which but a moment before enlivened the grove, at their appearing is at an end, every bird seeking safety in con- 
40 GAME PRESERVERS AND BIRD PRESERVERS.

cealment or in flight.' No doubt, besides certain naturalists, it is our falconers who are anxious to make birds of prey more numerous; but what would our keenest coursers think of a proposal that greyhounds should be allowed to breed wild, that they might have the pleasure of seeing a course occasionally without being at the expense of keeping up a kennel ?

When any account of the destruction caused by wild hawks appears in any of the papers, quite a little clique rush to the rescue, and assuming a monopoly of all knowledge of the habits of birds, try to prove their favourite innocent, though they get involved in the most hopeless contradictions. To read what they write one would fancy that hawks fed on insects and grass during the spring and summer, though occasionally in the autumn, in a fit of rough playfulness, they will kill a bird which by a provision of Nature is always a weakly one. One gentleman told us not long ago, that if we would only study natural history we should not 
think that falcons and sparrow-hawks inflicted much suffering on birds. Were a race of superior beings who perfectly understood the natural history of mankind to introduce from the planet Saturn a race of flying dragons, each of which would require a fresh-killed human being each day for its subsistence, would their presence inflict much suffering on us? Our stout and invalid friends, never venturing out of the house, would represent the badly diseased grouse which, it is allowed, the falcon seldom kills. Our bold and active friends often falling victims would represent the old cock grouse which ' Peregrine' tells us are frequently caught, while our women and children being most generally captured would prove the truth of the saying that the hawk kills the weakest bird, and we should also have an idea how their presence was likely to improve the health of the breed.

No bird keeps a better look out for hawks than our domestic turkey. Doubtless they are 
extensively preyed upon by them in their own country, and it is curious to see how the instinct so long dormant revives wherever they are exposed to their attacks. They have a soft gentle cry which the youngest chick knows means ' conceal yourself or you are lost,' quite different from the quick sharp call which means 'run in all directions,' which is the command if a cat or weasel appears. On one occasion we heard this cry repeated in several directions, and seventy turkeys managed to disappear from view quite as suddenly as Rhoderick Dhu's famous band did at his whistle.

Two buzzards were soaring over-head, and continued circling over them for some time until the old turkey cock's nerves finally gave way. Tucking in his feathers until he looked half his usual size, he ran for the house screaming with terror, a perfect picture of abject cowardice.

We once found a sparrow-hawk perched actually on one of the coops, and master of the 
situation, when we went to feed some pheasants early one morning. They had all escaped, but they did not return for three hours and their peace of mind was gone. For days afterwards, at the slightest alarm from one of the hens, or at the mere sight of a passing gull, they would all disappear from our very feet into a neighbouring piece of potatoes with a celerity which was quite wonderful.

Let any mother imagine that she has to give her children all their meals in the open air, where they are likely to be seen and carried off by an eagle at any moment, their chance of safety consisting in her keeping watch and screaming 'hide' when he appears, upon which they must all dive headlong under the table, and she will have some idea of the situation.

The inhabitants of an Indian village which is infested by man-eating tigers could understand better than we can the position in which birds are placed in countries that abound with hawks. 
44 GAME PRESERVERS AND BIRD PRESERVERS.

Khismat ki bhat, ' It is the will of Providence!' exclaim the unfortunate survivors as relation after relation disappears. 'It is the will of man!' may our poor birds exclaim as their numbers are thinned day by day.

Professor Newton tells this Committee, ' There is quite a healthy feeling growing that hawks should not be killed;' and we are told that the Duke of Sutherland, Mr. Cunliffe Brooke, and others are carefully preserving birds of prey in their large estates. Do these gentlemen realise that every pair of peregrine falcons, sparrow-hawks, and merlins which by their orders are reared on their property, will the next year destroy at the very least 1,000 birds, all beautiful and most of them useful to man?

Any naturalist who considers this an exaggerated statement will find himself in this dilemma: he must assert that one of these bircls, say the falcon, having breakfasted soon after daylight on one day, while taking an 
immense amount of exercise in the keen mountain air, will not taste food again for 48 hours, which we think few will believe. Or that he will eat carrion, which is known not to be the case. A bird a day is probably the minimum each hawk will kill for himself. That amounts to 730 birds for the pair. But in rearing their three young ones (and the sparrow-hawk and merlin have more than three), from the time they are hatched in the month of May until they drive them away in the autumn, 100 birds for each young hawk will be found a very small allowance, yet this makes 1,030 birds; and we are far under the real estimate, for we have known a pair of falcons watched and seen to bring six grouse to their young ones in four hours, shortly after they had left the nest, the young hawks rising a little way each time to meet their parents in the air, snatching the birds from them, and descending to fight over them. This is the actual destruction, and will some naturalist 
46 GAME PRESERVERS AND BIRD PRESERVERS.

calculate the indirect destruction, as each bird killed between February and June is either father or mother and a whole brood is lost? And are assemblies to pass laws for the preservation of birds, to prevent schoolboys and bird-catchers from killing them, and yet preserve these creatures? 'Save us from our friends,' must be our poor birds' cry.

The large hawks often hunt in couples. Once in India a flock of teal came towards us, high in the air, and two fell to our shot. As they were falling we heard a rushing noise, which our companion afterwards compared to the fall of a 21-inch shell, and as the teal fell at our feet, literally in the rebound each was seized by an enormous hawk, and carried off; but we shot the leading bird, and his mate then dropped her prey and escaped. It was quite common for kites to pick up our snipe while we were loading; but these hawks were evidently following the teal before we fired, and we always noticed when they dashed in among 
a flock of ducks high in the air that the flock would open, some ascending, some closing their wings and falling like stones to reach the shelter of the trees, and it was these last birds which the hawk always followed.

Once in Scotland a mallard rose out of shot from a little loch, but was soon seen returning hotly pursued by two falcons. He had a long start, and had just reached the water when down came the female, and though he partly dodged the blow she knocked him down, probably with her wing, at the water's edge, and seizing him by the back with one foot and a bunch of heather with the other, she held him in spite of his struggles, screaming all the time to her companion, 'Come and help! come and help!' And coming he was as fast as wings could carry him, when he detected the head keeper not seventy yards off also hurrying up to join in the fray. He gave a sharp cry of alarm; the other directly let go the duck, which escaped on to the loch apparently unhurt, and made off. . 
48 GAME PRESERVERS AND BIRD PRESERTERS.

Hawks which overtake their prey on the wing constantly strike them dead in the air. The frontispiece to that charming book, ' Game Birds and Wildfowl,' by Mr. Knox, 'The Death of the Mallard,' gives a capital illustration of this. It is with the powerful hind talon that the death wound is generally inflicted, but as hawks sometimes miss their blow altogether, so they occasionally strike more fully than they intended.

Then, as Mr. Knox expresses it, 'It is the breast-bone protected by such strong pectoral muscles that the concussion which deprives its victims of life can have no injurious effect upon the author of the momentum, which causes the injury. This is no doubt sometimes the case, and we believe the hawk fears concussion with the bird he pursues no more than a strong boy fears charging another at football. The best instance that we ever saw of this was when we once put up a hen grouse in the month of February, which was immediately 
pursued by a merlin. On coming over a ridge which had concealed the birds from our view, the merlin rose from the heather; and on going to the spot we picked up the grouse, which died in our hands. This grouse weighed $24 \mathrm{oz}$. The skin was not broken, but she had a tremendous bruise over the spine.

On two occasions, when beating the jungles in India we saw pea-fowl killed in the air by hawks. They fell among the trees with an unmistakable crash, like the fall of a pheasant shot clean. And we know a keeper who saw a heron killed in the air. It fell close to him, and he picked it up before the hawk descended. The grand sudden death of these great birds is certainly very different to the pictures one sees and the descriptions one reads of the way tame hawks take herons. After getting a little above them, they seem to settle on their backs (binding is, we believe, the correct term), and they descend to the earth 
50 GAME PRESERVERS AND BIRD PRESERVERS.

together, scratching and fighting like a bagful of cats.

There are two sorts of eagles-the golden eagle and the sea eagle; and six sorts of hawks -the buzzard, the hen harrier, the peregrine falcon, the sparrow hawk, the merlin, and the kestrel_-still found in the British Isles.

We will try all these creatures for their lives, and see if they offend, or how far they offend, against the law we wish to pass to enable our birds to breed in peace.

Then we have still some beasts of prey in Great Britain. There is the mountain fox, the cat, the polecat, the stoat and the weasel, the rat and the hedgehog. These are all suspicious characters. We will enquire how they spend the summer months.

A few other species are occasionally met with, such as the goshawk and the marten cat; but they are rare. 
51

\section{CHAPTER V.}

THE EAGLE, THE BUZZARD, AND THE HEN HARRIER.

A PAIR of fishing eagles bred every year on a rock overhanging the sea at one extremity of our shooting manor, and we never disturbed them. One season the head keeper was lowered by a rope, at some risk, and took the egos for the owner of the property. They were three in number, very large and white. The nest was made of a mass of sticks. They never took lambs; but white hares were very scarce at that end of the ground, and we hardly ever saw a grouse within four miles of their nest. Possibly their mere presence passing backwards and forwards so often may have frightened them out of the country. 
Had we a deer-forest, and golden eagles bred in it, we would protect them to keep down the hares. The hinds conceal their fawns when quite young so well that they would seldom find them, and after they are strong enough to follow their mothers we should think they would be safe.

But they will take lambs. A very intelligent shepherd told us that when he was employed in the Island of Rum in one season he lost more than seventy lambs by eagles. His employer then bought him a gun, and in the next eleven years he killed forty golden eagles by exposing dead sheep and building a hidingplace near them. Mr. R. Gray thinks they would be more likely to take a sickly lamb than a healthy one; that the mother would be able to defend a healthy one. We have but little faith in these theories. When an eagle has swooped down upon a lamb it is its weight, and not its state of health, that will settle the question whether he carries it off or not. $\mathrm{He}$ 
THE EAGLE, BUZZARD, AND HEN HARRIER. 53

will not feel its pulse nor enquire how it is; and shepherds say they will not. take them after they are three weeks old; while if the ewe has the courage to charge the eagle and literally to send him 'flying;' she would do this whether the lamb was strong or weak. Mr. Gray does not think they will eat carrion. It is fortunate that they do, or they would be far more destructive than they are. We know a keeper who trapped two which were feeding on the carcase of a dead hind.

Mr. Bonner, in a book called 'Forest Creatures,' lays it down as a well-known fact that they will fast for days together. This is the sort of statement that it would seem impossible to prove; for what man has ever watchedan eagle from sunrise to sunset? though were he heavily to gorge himself late in the evening he might perhaps be seen sitting on the same rock the whole of the next day.

They are still more numerous than people imagine, and we see a few every year in the 
54 GAME PRESERVERS AND BIRD PRESERVERS.

Western Highlands, but we know but little about them.

The buzzard is the next largest bird of prey, and it will also live a good deal on carrion, and is easily trapped. It will also rob the falcon of his prey, the latter making no objection; in fact, rather liking the fun of catching another bircl. It takes but few grouse except when they are young ; but, 'small blame to it,' it is only because it cannot catch them, unless it takes them by surprise. It will snatch a grouse from her nest, or a grey hen from the ground as she sits cowering over her little ones to cover them from the pelting of some sudden storm. Their legs and wings are found round their nests. Do people realise the sufferings of these young birds when their mothers are taken? They call and call, for they are so sure she will return. She always has when she has had to leave them before when the shepherd or his dog have come too near. But the cruel cold night comes down upon them, and their little calls get 
THE EAGLE, BUZZARD, AND HEN HARRIER. 55

weaker and weaker, and long before morning they are all dead. We do not like these birds; but if any gentlemen do particularly like to see them sometimes flying round and round in lazy circles, we do not fancy that their presence on a well-stocked moor will very materially reduce the number of grouse, and they will no doubt be glad enough to take a sick or wounded bird. We have known them make their nest on the ground at the edge of a ravine, and they lay three eggs of a dirty white colour.

The hen harrier is scarcely mentioned to the Committee at all. It is rare, and it is desirable it should remain so. The difference of colour between the plumage of the male and female is most striking. The cock bird at a little distance may be taken for a sea-gull. We saw an old female shot last September, as it rose from the body of a half-grown hare, and we shot another as it was in the act of killing an old partridge in January. They are difficult to 
56 GAME PRESERTERS AND BIRD PRESERTERS.

shoot, as they frequent the open country, and they build on the ground among the heather.

One spring some cattle taking alarm at some dogs, which were out with the keeper, running through the heather put up a hen harrier, and actually trod in the nest and broke all the eggs. This bird, however, laid again and reared a brood on the same hill and very near the same spot. They thinned the grouse most cruelly. It was the best breeding season we ever saw, and packs were all large where they bred in peace, but very few in that part of the country numbered more than four birds. We found five packs in succession each numbering four.

The old male, when he was shot at last, had his crop full of wire-worms. Probably he had been recommended change of diet for a time. We do not believe that Nature gave him those long wings, and that hooked beak, and those cruel claws to hunt and catch worms with as a rule. Her worm-hunting children are differently armed. Harriers fly 
THE EAGLE, BUZZARD, AND HEN HARRIER. 57

low, quartering their ground and hovering over a bird like the little kestrel, only much nearer the ground. One so terrified some partridges while doing this that they let us catch them. Once in the Arnatola Mountains we found a low thick bush crowded with poor birds of the thrush tribe, and two harriers hovering over it. These birds let us catch them, and we were cruel enough to throw one up in the air. The hawks were after it directly; but it turned back and settled at our feet, and we shot the hawk. We do not know if they will eat carrion; but fancy not, as they were never caught in the traps which caught the buzzard.

The female was on the ground all the year round, and would come near the houses in the winter; but the male disappeared every autumn, returning in the spring. It was two years before he was shot, though we put ten shillings on his head. He looks very well in a glass case now, and that is the proper place for all the breed in our opinion. 
58 GAMIE PRESERVERS AND BIRD PRESERVERS.

We have several times seen them overtake partridges, and once saw them overtake grouse on the wing, but they either cannot or do not wish to strike their quarry in the air. On each occasion the hunted bird closed its wings and settled. The hawk then hovered over it for a moment, and then pounced on it. 


\section{ว9}

\section{CHAPTER VI.}

THE FALCON.

'Falco Peregrixus,' the wanderer, is by far the noblest of our birds of prey, for, while the eagle will condescend to feed upon carrion, we never knew an instance of a falcon being detected in doing this. In fact, he will not even return to his quarry if once disturbed from it. Several of the witnesses whose evidence is before us wish to preserve him, thinking he will act the part of a wise physician and cure the grouse of their disease. Professor Newton

' thinks him 'harmless,' but states he used only to see one 'for three weeks in the year, and then he generally killed pigeons.' None of these gentlemen mention their habits in the breeding season, and it is curious to observe 
60 GAME PRESERVERS AND BIRD PRESERVERS.

how little is known about their numbers. Even Sir D. Wedderburn says: 'I suppose one could count on one's fingers the nests of the peregrine falcon which are in England, Wales, and Scotland.' Why, last May, while standing within shot of a falcon's nest, from which we had just killed the old bird, we could see with the naked eye five other rocks or mountains on which, to our certain knowledge, they have bred regularly until quite recently, and on which they are each year trying to re-establish themselves. The furthest of these nests is not quite twenty miles from where we were standing; the others very much nearer. And we know of two other nests in the neighbourhood. These birds seem to depend more for protection on the very lonely nature of the spot selected for their nest than on its inaccessible situation. It is easy to climb within shot of nearly all the nests we have seen, and some of them may even be robbed without the aid of ropes or ladders. 
In Meyer's 'British Birds' the nest is said to be composed of sticks. We have found nothing but a slight hollow scraped on the bare rock, a fit cradle for these bold and hardy birds. The eggs, three in number, are of a handsome, rich, dark red. Generally, one is much lighter than the other two. Few people have the slightest idea how destructive they are to all the birds we most value. This arises a good deal, we believe, from naturalists examining the contents of their nests generally in parts of the country where game is nearly extinct, and, of course, finding few traces of it. Or a single pair are occasionally tolerated, as Lord Lilford states, in districts like certain parts of Perthshire which are so peculiarly favourable to grouse, and where, from all other vermin having been for many years carefully destroyed, grouse are so very numerous that the depredations of the falcon are scarcely noticed; and sportsmen bag thirty or forty brace a day instead of sixty or seventy 
brace. But their presence in the Western Highlands turns the balance, and makes the difference between estates being worth shooting over or not; and proprietors in this part of Scotland will never know what rental their estates will produce until the falcon is about as rare as the great auk. As an instance, we know a fine estate which has been let for the last three seasons for 500l. a year, which for nine years was neither let nor shot over, though three and four keepers were kept on it all the time.

The grouse never increased, and five brace was an unusual bag. Since three falcon's nests were discovered in the neighbourhood, and they were regularly prevented from breeding, from twenty to thirty brace has become quite an ordinary bag. The presence of these birds on the ground made a difference of $800 l$. a year to the proprietor, as the estate cost at least 300l. a year to keep up instead of bringing in a clear $500 l$.; and a number of 
other estates are doubtless similarly situated. Only last summer a gentleman wrote to us that he could not account for game being so scarce on his shooting grounds under such seemingly favourable conditions. Before we had been three hours on the ground the mystery was explained. We found a falcon's nest. For these birds break up nearly every pair of grouse in the breeding season. Between the months of February and July either the cock or hen is nearly sure to fall a victim. They seem to leave this part of Scotland in October. We have never seen them between that month and February, except once on January 29. It is easy to know when they return. If you are out on the hill with the young dogs and one of them draws a little, then hesitates, and then walks in to smell at something, if you go to the spot you will find the earthly remains of what was a few hours before a fine specimen of 'Lagopus Scoticus.' He will be lying on his back, with his head 
64 GAME PRESERVERS AND BIRD PRESERVERS.

pulled off; his bones will not be broken, but neatly picked. A long trail of feathers will mark the place where he received his deathblow. Then remember the message which King John received when Richard Cœur do Lion escaped from prison: 'Take heed to yourself; the devil has broken loose.' And if you cannot kill this murderer, you will find these signs of his presence whenever you walk on the mountains.

Would the gentlemen who wrote so smoothly, "Spare your birds of prey, particularly the falcon; he will kill the weak birds and leave the strong ones to breed,' be contented to see their favourite poultry treated in this manner? And every grouse killed between February and July is a whole pack off the ground in August. When they have once paired and selected their breeding ground, if they are killed, none come that year to supply their place. In 1871 , suspecting that a pair of falcons had intended breed- 
ing on a certain mountain in the heart of our best shooting ground, we went carefully through it in the middle of May, when the hen would be setting, clapping our hands and shouting under each likely rock, but, seeing nothing of them, thought all was safe, and that they had left. Early in August a shepherd brought us word that some large hawks on that farm were mobbing his dogs. The keeper went to the spot, and found that they had bred on the very rock we had most carefully examined, the hen being too cunning to show herself for the noise we made. Next day we took out some dogs, with which we had found fifty-two brace of grouse in three hours a few days before, and hunted that country.

We saw five barren brace, one covey of squeakers, and three odd cocks. These barren braces were the birds whose mates had been taken, and which paired afterwards, but too late to breed. The remains of grouse were scattered 
66 GAME PRESERVERS AND BIRD PRESERVERS.

all round the rock, and they were equally scarce in all that part of the country; and they had supplied their young so abundantly that many of the birds they had brought them were not half eaten.

Mr. R. Gray says their favourite food is a snipe. We have never seen one in their nests or near them; but if they bred near a place where snipes were numerous, and other birds not to be had, no doubt they would take them. Our experience is that five out of six birds they take are grouse or black game if they are to be had in the country. They are the most easily caught and the best eating, so it is only natural they should eat them. They also frequently kill birds for sport. The poor gulls, conspicuous in their white plumage, are often struck down and not eaten; and a shepherd once brought us a kestrel, which he saw a falcon kill without taking the trouble of following it to the ground.

Some falconers ask, How is it possible for a 
falcon to kill so many grouse, for we all know that when a falcon is in the air they will not take wing? The wild hawk is too cunning to show himself as their tame falcons do, trusting to their allies, the dogs, to put up their quarry for them. He watches motionless on a rock, or suddenly appears over a mountain ridge, and if there are any grouse in the country at all they are sure sometimes to wander on to the bare, burnt ground where the young heather is so sweet. He is upon them like a whirlwind, though whether he will actually strike them on the ground is a disputed question. We know he will skim a young wild duck from the surface of the water, and the feathers near the remains often show that they must have been struck close to the ground; probably in the act of rising.

One gentleman wrote to the papers advising keepers to preserve peregrine falcons to reduce the number of hoodie crows, because he had a tame tiercel which lived on rooks when 
68 GAME PRESERTERS AND BIRD PRESERVERS.

it was at liberty. No doubt the poor hungry creature was glad to make a meal of any bird it saw passing, and had not the wit to find game birds which naturally concealed themselves whenever he appeared; but our head keeper in fifteen years had not only never seen a falcon kill a hoodie crow, but has never found the remains of one which seemed to have been killed by a hawk.

We have known a pair of crows build and rear their young on a solitary tree on an island in the middle of a small loch in the centre of the hunting ground of a pair of falcons where the remains of grouse and ducks were found every week. We ourselves twice saw the falcon strike at one of the crows, which, by a sudden change of front, turned in the air and presented beak and claws to the attack, and the hawk seemed to fear to charge home. These were the tactics adopted by two pair of ravens which bred on the same mountain as these falcons. They were always fighting when the falcons 
first arrived in the spring, and it was very amusing to watch them; but they cared nothing for their attacks, and ultimately settled down to an armed neutrality.

There must be an establishment for unmarried female falcons somewhere. The male never seems to have any trouble in procuring a mate. We have known one procure three in a few weeks. It is also curious how they will continue to frequent rocks on which they have once bred. In 1874 the eggs were taken from one rock and a female was shot on another, although to our certain knowledge the young have not taken wing from the nest on either rock since 1869 , and every year since that time at least one bird has been shot at each of those nests. They are very rarely seen, and their presence on a property is often not suspected. Although one summer we saw fourteen on wing round their nests, during the following shooting season we never saw one, though we constantly came on the remains of birds they had killed. This was 
70 GAME PRESERVERS AND BIRD PRESERVERS.

because they generally feed soon after daylight, and then retire to the most lonely rocks to spend the day:

We should greatly like to see some of the gentlemen who write, 'Let them be shot if inconveniently numerous, but not in their breeding season,' take a vow to drink no fermented liquor and to taste no meat until they had shot one after August 1. They would find the pursuit of the Holy Grail quite as easy a quest. If they happened to discover the mountain on which they were it would be only to see them take wing, probably at a distance of at least 300 yards, and they would most likely cross an arm of the sea before they settled again. Once on a 6th of August we saw a party of five come across the loch to us. They were all flying in wide circles like a convoy of ships with sailing orders to keep in sight of each other, occasionally screaming to each other, every now and then dipping down till they were near the tops of the hills, then suddenly rising again high in 
the air. It was a pretty sight; but we did not think it repaid us for the consequences, should they have honoured us by staying a fortnight on our mountains. But we did not go out falconshooting the next day, for we should not have known within twelve miles in any direction where to look for them.

We do not suppose the cat or the fox ever lived who ever caught one. They can have no enemy but man, and generally die of old age.

We gave ten shillings for each one that was brought us, but with four guns always out we never during six years knew one killed between the months of July and March. We paid one man, however, for seven before the middle of May in one year. These birds were all shot before an egg was hatched. We never left their young to starve, as they are every day leaving the young of other birds. As Dr. Günther tells the Committee, birds of prey ought to be destroyed during their breeding season because ' it is then 
72 GAME PRESERTLRS AND BIRD PRESERVERS.

they are cloing the greatest amount of mischief; and you cannot protect useful birds in a better way than by destroying their destroyers.' They return to the rocks upon which they breed to roost many weeks before they lay, but it is weary work waiting for them. No keeper cares to attempt it for the sixpence he gets for them simply as a hawk. You must be hid early in the afternoon, as they may return early, but it may not be until sunset, and then perhaps only to settle just out of shot, and if you move to get nearer they are off for that day. A pair which bred on a lonely little island used to return so high as to be scarcely visible; then, closing their wings, they would fall like stones till they reached their favourite rocks. About a week before they hatch the hen will sometimes sit so close that she will not leave the nest unless a shot is fired. We knew one sit on the nest and scream at us as we clapped our hands within thirty yards, but she would not fly.

'Inconveniently numerous!' What a curious 
expression! How many of his breeding stock of Dorking hens and Aylesbury ducks does a man like killed by wild beasts in the spring? And how many of our breeding stock of beautiful grouse are we likely to wish destroyed when we know that if every bird which is alive on the ground in February is alive in August, we shall hardly average, with the help of the best dogs, twenty brace a day?

But these birds will always be encouraged in the deer-forests, and very properly, on purpose that they may kill down the grouse.

No bird ever renders himself so perfectly hateful to man as an old cock-grouse, who, when you have perhaps but another hundred yards to crawl to be within shot of the finest ștag you have seen that season, rises before you and flies straight towards him, crowing and chattering all the time. For that beautiful beast has not lived in this wicked world long enough to develop those twelve points on those wide- 
74 GAME PRESERVERS AND BIRD PRESERVERS.

spreading antlers without learning a thing or two.

He will certainly interpret that wild cry to mean 'The Philistines are upon you, Samson!' and before you can reach the top of the ridge in front of you he will be cantering over the opposite one five hundred yards off, perhaps pausing for a second on the sky-line to look back at you, and then that splendid trophy is lost to you and your heirs for ever.

Now were a falcon to 'come out of the clouds, and kill that grouse and tear him to pieces before your eyes, the punishment would be inadequate to the crime he has committed. Perhaps it is hours since you found that stag; you had to make such a round to get the wind. And the great burn was in spate, and you could only cross in one place, and then it was up to your middle.

Now it is beginning to rain and blow as it can rain and blow in the end of September in the mountains. It will be dark long before you 
reach the lodge, and all the way you will be thinking how out of place grouse are in deerforests.

Let naturalists be content to follow the falcon to these splendid great wildernesses, and study his habits there, and not try to introduce him on our grouse-moors where he is less wanted, and infinitely more destructive than he would be in our drawing-rooms.

And we are perfectly aware that there are parts of these deer-forests where grouse are far from scarce, although surrounded by their enemies. But these are favoured spots so peculiarly suited to them that they will come in to breed there every year,

Each stepping where his comrade stood The instant that he fell. 
76 GAME PRESERVERS AND BIRD PRESERVERS.

\section{CHAPTER VII.}

THE SPARROW-HAWK, THE MERLIN, THE KESTREL, AND THE OWL.

The sparrow-hawk is the next most destructive hawk that we have. He combines both methods of attack; either overtaking his prey by fair speed on the wing and dashing it to the earth like the falcon, or pouncing down upon it and lifting it from the ground like the buzzard or hen harrier. He can catch old grouse, partridges, and pigeons, in the winter, and pick up young pheasants in the summer as fast as they are hatched. A gentleman wrote to one of the papers a few years ago that he had counted the remains of seventy-three young pheasants under one sparrow-hawk's nest. Lrrd Lilford tells the Committee that ' it will destroy an in- 
SPARROW-HAWK, MERLIN, KESTREL, AND OWL. 77 credible number of young game.' Even Professor Newton gives it up. But several gentlemen seem to value a bird exactly in proportion to the misery and destruction which it causes to other birds, and wish to preserve this one. The Rev. H. B. Tristram says that it will live ' entirely on the wood-pigeon.' We should be sorry to trust it. We think it would rarely carry so heavy a bird to its nest, and it is when feeding its young that it is most destructive.

We saw one dash down and seize a young turkey close to the house, but the turkey hen with great presence of mind immediately knocked it over, and it was glad to beat a retreat, followed in the air for at least fifty yards by the old turkey. The young ones all concealed themselves, and it was an hour before they ventured to reappear, the old bird walking round and round and keeping guard in a great state of excitement.

Very shortly afterwards, we were watching from an upstairs window a gold cock-pheasant 


\section{GAME PRESERVERS AND BIRD PRESERVERS.}

feeding in an open wire pheasantry, and wishing we had twenty-five instead of seven of these birds, when like a flash of brown lightning down came a sparrow-hawk at him. The pheasant is a particularly sharp bird, and is as rarely found fast asleep as the proverbial weasel. This one was equal to the occasion. He neatly dodged the hawk; and, with his friends, retiring to the shelter of a large thick bush which grew in the middle of the pheasantry nearly as quickly as his enemy had descended, 'Accipiter Fringillarius' found him . self on the ground with all his wind knocked out by the wire netting, this netting being a feature in the landscape which had escaped his observation. He felt that his position was a false one, and tried to escape by flying round and round against the wire instead of ascending; and we complicated matters by arriving at the scene of action with our gun, and, though he cleverly managed to keep the bush between us for some time, we ultimately shot him. Now this hawk's conduct was umpardonable. They had 
SPARROW-HAWK, MERLIN, KESTREL, AND OWL. 79

been systematically killed for years, so their natural food must have been most numerous, and it is a sufficient answer to the recommendation of some naturalists to let these birds breed in peace, and, 'if they become too numerous, to destroy some of them afterwards.' Too numerous! We believe this was the only bird of the sort in the whole country, and he was exactly one too many.

We could mention many other instances of the destruction and mischief done by these hawks. We will kill them as long as our guns carry shot, and advise all occupiers of land who love harmless birds to do the same.

We are sorry for the little merlin; he is such a handsome little rascal ; but he is a dreadful bird murderer. They are scarce because their real character has been found out. Were they allowed to breed undișturbed they would soon become numerous, and other birds would decrease in an alarming ratio. It is not as a game preserver but as a bird preserver that 
SO GAME PRESERVERS AND BIRD PRESERVERS.

we destroy him; though, as we have stated, we have seen him kill full-grown grouse. We simply cannot spare a pair of them a thousand birds annually. If he would only eat grass and wild flowers we should be glad to see him, but he will not until the lion lies down with the lamb. We believe it was Sydney Smith who observed that if the lion ever does this, while his digestion continued to be what it is, it will be with the lamb 'inside him.'

The merlin must disappear, and let all landowners console themselves by introducing at least two sorts of pheasants in his place.

The kestrel is the only wild hawk most people ever see. He is a pretty object, hovering in one spot for minutes at a time. His manner of hunting is so different from that of all the others, it suggests at once the idea that he is pursuing a different object. When mice are plentiful he seldom takes birds; but he will not starve, and he well knows that the little newly-hatched pheasants and partridges are not bad eating as a change. 
SPARROW-IIAWK, MERLIN, KESTREL, AXD OTL. 81

If we were getting up game when it was very scarce we would not allow the kestrel to breed on the ground at first. But where game is plentiful, we should preserve him only on the condition that he dicl not carry off our pheasants.

It is because some naturalists attempt too much that they are not listened to. What is the use of their telling keepers that the kestrel will never kill a young bird, when these men have nearly all at some time or another shot him in the act? If he carries off a young wild bird, he may never find that brood again. The hen will probably shift her ground a little. But our hens are cooped in comparatively bare places; and when he once finds out how easy it is to procure a meal, he will return time after time until there is not a bird left. Are we really supposed to tolerate this any more with pheasants than with turkeys or chickens? A keeper may have had bad luck with his pheasants' eggs and have hatched but few, and 
these are to disappear at the rate of five or six a day; but it is all right. He must not interfere; it is only a kestrel. This is an unusual case, but when it happens this bird should be watched for and shot. He is exceeding his orders and wandering out of the path of duty.

The owl will much more rarely offend in the same way. We never had an owl shot, but they never increased in the Highlands. Probably the climate is too wet for the mice. They had plenty of ivy-mantled rocks, if not towers, to breed on, but two pair were all we ever saw.

As a hawk can rarely kill a rat because he is a nocturnal animal, so an owl can rarely kill young game birds because they are nearly always asleep when he is about. But instances will occur; there is no use in denying it.

An owl is returning later than usual. It has been a wet night, and he has had bad luck. The mice preferred ' to sit by the fire and spin.' $\mathrm{He}$ is low-spirited, for he knows that Mrs. 
SPARROW-HAWK, MERLIN, KESTREL, AND OWL. 83

Owl will be cross and snappish all day, and the young ones will be waking him up and crying for food long before sunset. And 'what lungs that eldest boy has!' The very remembrance makes him give a plaintive hoot. He sees some little brown things. Perhaps he has as much real courage as the man who ate the first oyster. He takes one home and it is pronounced excellent. Could not he just glide out and get another? He does, and day after day until watched for and detected in the act. Then the whole race are condemned; but let gentlemen give orders that owls are not to be killed unless so detected, and let them take steps to see that they have owls on their property, and perhaps not half a dozen in all England would be shot in a year.

The owl is the very best mouse-destroyer we have, and a most interesting object on a summer evening. 
84 GAME PRESERVERS AND BIRD PRESERVERS.

\section{CHAPTER VIII.}

THE RAVEx, THE CROW, THE MAgPIE, THE JAT, AND THE ROOK.

THe raven is a bird which most gentlemen agree ought to be exempted from protection. Mr. R. Gray says 'it is well known for its cruel rapacity on sheep farms.' Dr. Günther considers it very mischievous. It is not so rare as some people think. We have seen twenty-six in a flock, and it is cunning enough to breed often in such inaccessible situations that it is not likely to become extinct for many years. The nest is composed of a mass of sticks placed on the ledge of a rock, and it lays generally three eggs as early as the end of March, so that the young ones are strong 
RAVEN, CROW, MAGPIE, JAY, AND ROOK. 85

about the time when most of the grouse are hatching. It has a most cruel habit of attacking the eyes of any weakly sheep or lambs. It is not uncommon to find these poor creatures alive on the hills with their eyes pecked out. One we reared always attacked the eyes of any rat or other dead animal directly it was thrown to it, and it would swallow addled pheasants' eggs whole one after the other. A dirtier or greedier pet we never saw, with nothing to recommend it but an odd way of hopping sideways, and a curious trick of hiding its food. If it does this in a state of nature, it must be on the same principle that we hang venison until it is high enough to eat.

When it had been out of the basket but a few days, as it was hopping along in the garden, a young hedge-sparrow fluttered up out of the grass. The raven was after it in a moment. No well-bred young terrier ever charged his first rat in better style. The unfortunate little bird was caught and swallowed whole, with a croak 
of satisfaction, in spite of the exertions of three people to save it. No one who saw the action could doubt that young birds are the raven's natural food, and from that moment we put 'Corvus Corax' on our condemned list, and there he shall remain.

For we pictured to ourselves the innumerable tragedies which must be going on where these birds exist-the happy families of young and old grouse enjoying the spring sunshine and the tender shoots of the heather-the sudden descent of the sable crew-the screams and helpless terror of the old birds, the feeble efforts of the little ones to escape, all unavailing, only one under an old heather stump managing to hide so that those keen eyes cannot find him. And when some months later the sportsmen walk up to the beautiful setters which have suddenly dropped motionless, only quivering a little with excitement, it will be three grouse, not ten, that will rise before them. Should anyone say, how- 
RAVES, CROW, MAGPIE, JAY, AND ROOK. 87

ever, that these birds may as well have died so as before our guns, we say 'No.' Will any parent look upon the death of a child that dies by the chances of war in the prime of life in the same light that he regards the death of one killed by a wild beast in his cradle? And again, if the grouse which Providence places on our mountains are to be eaten at all, we think we make a better use of them if they are eaten, after being properly cooked, by our friends, than if we allow them to be swallowed in their infancy like oysters by ravens, just to give them an appetite for their pièce de résistance, the braxy sheep on which they will probably dine before night.

When we reflect that these birds are gifted with keen powers of vision and great powers of flight, that after the young leave the nest they fly about in family parties with nothing to do through the long summer days but seek for food, we wonder that any grouse escape them at all. The fact is that but few do 
escape them, and we have the raven, et loc genus omne, to thank if grouse are five shillings a brace instead of two shillings a brace in our markets, and if thousands of square miles in Scotland still afford neither sport nor rental to their owners. Yet so little is practical natural history really understood that plenty of people are agitating even now to make creatures of this sort more numerous.

To do the raven justice, however, we must own we have no braver bird, for he will singlehanded attack the eagle, and hunt him clean out of the country. One day in April, when watching for falcons near the top of a lofty mountain, we heard sounds that reminded us of the screams of an African baboon. An eagle had come too near to a raven's nest, and the male was driving him away. However high the eagle ascended the raven was always above him, and kept dashing down on his back, no doubt giving him most unpleasant digs with his sharp bill, the eagle resenting each attack by uttering the most 
RAVEN, CROW, MAGPIE, JAY, AND ROOK. $\$ 9$

grotesque cries. We watched them till they were lost to sight in the distance, the raven returning some minutes afterwards at a great height.

The carrion crow, the hoodie crow, the magpie, and the jay may be classed under one head. They feed upon the eggs and young of all the birds which are most useful to man, and they were evidently intended to keep down their numbers. When he begins to understand how to make the best use of the blessings which surround him, they had better join the mastodon and the ichthyosaurus. 'Othello's occupation is gone.' And no services they can perform as insect-destroyers make amends for the injuries they commit. Besides, these services are still better performed by the rook and starling. Yet Mr. Waterton's disciples are fond of relating how many carrion crows' nests there were always at Walton Hall. This is mentioned by Mr. A. Ellis and by other witnesses before this Committee. Did Mr. Waterton or 
90 GAME PRESERVERS AND BIRD PRESERVERS.

any of his friends ever calculate what was likely to be the smallest number of eggs ever taken in a breeding season by the very idlest and least skilful pair of crows in his park? At the rate of one nest a week it would amount to hundreds, and a really energetic crow would generally find one a day. When as schoolboys we collected birds' eggs, how we envied these birds, who had neither morning nor afternoon lessons, who did not know what out of bounds meant, and whose life seemed one long whole holiday! We hold the opinion that if a man is so fortunate as to have such a valuable treasure on his land as a dozen grouse, partridge, or pheasant eggs, the best possible use he can make of them is to take what precautions he may to see that they turn into twelve beautiful birds. To watch them from the day they are hatched is most interesting. To follow them and thin their numbers in autumn will give him or his friends exercise and amusement, and his invalid friends, jn particular, will be 
RAVEN, CROW, MAGPIE, JAY, AND ROOK. 91

only too glad to eat them. Some people seem to think the best thing to do with these eggs is to get them eaten raw by certain black or black-and-white birds as soon after they are laid as possible. "We differ from them, that is all.

The numbers of these birds have been so reduced that their depredations are to a great extent forgotten. We remember, years ago, losing a whole brood of chickens by a carrion crow, and Mr. C. Russell states that he knew ' ten ducklings carried away by a magpie.' Was that a desirable state of things? We believe that if Mr. Waterton's system were universally adopted (and it is worthy either of imitation or condemnation), in ten years from the present time it would be difficult to rear either ducks or chickens unless under nets.

A man once told the judge who sentenced him to be hanged for sheep-stealing, that he thought it hard to be hanged for stealing a sheep. The judge told him he was to be 
hanged in order that sheep should not be stolen. We kill these birds in order that egrgs should not be stolen, and believe we do a rational action and a kind action to the many that depend on us for protection. We believe in the Communistic theory, 'the greatest happiness of the greatest number,' and do not doubt that fifty birds live for each crow, magpie, and jay which our keepers destroy.

We must own we once opened the crops of some full-fledged young hoodies, and found them full of insects, principally beetles. But then their ancestors had eaten eggs for so many years in that country that there were no birds left to lay any within three miles of their nest.

A most serious charge is brought against the rook by Mr. Scot Skirving. He states that they 'eat more game eggs than all other birds on earth. I have picked up as many partridge eggs under a rookery as would fill my hat. Every year we get six or eight 
RAVEN, CROI, MAGPIE, JAY, AND ROOK. 93

pheasants' nests, and, in spite of covering them with grass, the rooks eat them all.' These birds no doubt are old offenders, who in some unusually dry year have found out that eggs are good eating, and never forget it. We would indulge them. They should find plenty of eggs and nests; but there should be a trap at the entrance of each until we had got rid of them all. Then we would spare the young rooks, hoping, that when they grew up, they would not take to such vicious practices. 
94 GAME PRESERVERS AND BIRD PRESERVERS.

\section{CHAPTER IX.}

THE FOX.

Foxhuntixg has perhaps never been better described than by the famous Mr. Jorrocks when he called it 'the image of war without its guilt and only 25 per cent. of its danger-a sport fit for kings;' and the huntsman who in giving the toast, 'Fox-hunting,' said that 'he knew the men, and horses, and hounds liked it, and that he thought the fores did too,' was much nearer the truth than most people would think. They exist in Great Britain that they may be hunted. It is their raison d'être.

Will any of the gentlemen who write down foxhunting because it is so cruel a sport honestly ask themselves the question whether, if 
they were compelled to return to this earth and live as foxes, they would rather live in a country where foxhounds were kept, or in a country where there were none? Can anyone doubt, if foxhunting could be abolished by law, that in a few years foxes would be as rare in England as wolves are now? Look at the life a fox leads in countries where there are no hounds. He cannot creep through a fence without fearing to find his leg fast in a trap. He cannot eat a dead rabbit without fearing strychnine; nor can he appear outside a cover without feeling a charge of shot rattle about him, instead of being greeted with a joyful tallyho.

There is perhaps no happier animal than the English fox who lives in foxhunting countries. From the close of the hunting season till it recommences his life is one round of enjoyment. He is without an enemy, and lives without fear in the midst of plenty.

While cubhunting lasts, their numbers are reduced to a certain extent; but after that we 
96 GAMIE PRESERVERS AND BIRD PRESERVERS.

doubt if one out of every five that is hunted is killed, and a fox is very unlucky if hunted twice in the same season. A hunted fox always has previously escaped all dangers, and doubtless, till his powers begin to fail, hopes to escape again. Then he may pass un mauvais quart d'heure. But what are his sufferings compared to those

Of suffering, sad humanity, And the afflicted ones who lie Steeped to the lips in misery, Longing, yet afraid to die?

There is a great deal of unnecessary sentimentality wasted about some animals' sufferings, which are so slight compared to our own. Look at our cancer and consumption hospitals, for instance. We doubt if most of us would not compound for the troubles of various sorts which pursue us from year's end to year's end by giving the hounds a run once or twice in a season, even if we did deroutly pray over night that it might be a bad scenting day, and that 
certain of our hard-riding friends might be out to over-ride the hounds and help to save us.

Surely a fox who has escaped towards the end of the season, and who knows that his side of the country will not be drawn again for many months, may exclaim with Pope-

All partial evil is but general good,

as he watches the hounds trot along the road to draw other covers. It will be a sad day for 'the stately homes of England' if foxhounds are ever abolished, and we suggest to the serious consideration of the Secretary of the Society for the Prevention of Cruelty to Animals whether he ought not to bring an action against Mr. Freeman and other gentlemen who, like him, try to write down foxhunting, for, if they should succeed, they will condemn to cruel sufferings, by poison, trap, and gun, and to extermination, one of the happiest of our wild animals.

At present, however, the fox exists, and we have to consider how he is to live to do our 
98 GAME PRESERVERS AND BIRD PRESERVERS.

birds the least amount of harm; and no doubt the one thing to do is to allow a certain number of rabbits to breed in his neighbourhood. In fact, it is only as food for foxes that we would tolerate these creatures in cultivated districts. He will eat these and hares, rats, mice, and frogs, and what few birds he can catch. He will also take from their nests some hen pheasants and partridges; but we would not give him much opportunity of doing this, as we would take all of their nests that we could find ourselves, and rear their young in a place of safety. His attacks upon our poultry can always be prevented by wire netting, and the mesh can be so large that it is cheap even when six feet high. It is well worth while for hunt clubs to be at the expense of supplying this wire where they know that poultry yards are particularly exposed to the attacks of foxes, and so render the farmers' wives their friends instead of their enemies. We know some beautiful pieces of water, too, on which various sorts of wild fowl 
are kept, and the setting ducks are most provokingly carried off every spring. A few pounds spent in this wire netting and a few floating islands would entirely prevent this.

But what can we say for the mountain fox of the Highlands,

Whom hounds do ne'er pursue,

Who ne'er hears huntsman's halloo?

Mr. Frank Buckland, in one of his usual amusing papers a short time ago, describing what he saw on a visit to one of the Highland proprietors, published the list of vermin destroyed on this estate, which was shown to him by the manager, in a single year. At the head of this list were a number of these foxes; and the first thing that would strike most people would be, how very numerous these creatures were in spite of all efforts to reduce their number; and to wonder what would become of all the harmless creatures that abounded on this property, but for the protection man afforded them by destroying their destroyers. 
100 GAME PRESERVERS AND BIRD PRESERVERS.

But Mr. Buckland remarks at the end of his letter, ' I told this gentleman he was quite wrong to kill these birds and beasts, for that he was interfering with the Balance in Nature.' Had Mr. Buckland been visiting one of this gentleman's ancestors a few hundred years ago, and had he been shown the list of wolves which he had destroyed, would he have made the same remark, for that was equally interfering with the balance of Nature?

We can give no reason why the mountain fox should ever be spared. He must die whenever he may be met with, per fas aut nefas. $\mathrm{He}$ is rarely even seen by man. His presence in a country is only known by the death and sufferings of other useful and harmless animals. $\mathrm{He}$ kills our beautiful grouse. We have seen him when watching deer through a telescope stalk them and pounce on them. He catches the old birds at night, particularly in the snow, where we can see his tracks; and he takes the hen on her nest. A keeper of our own one 
morning at daylight shot a vixen, returning to her den, and in her mouth were a hen grouse, two grouse's eggs, and two frogs. He kills the hares, but this we could forgive, and the young fawns.

A keeper in the Lewes once observed a hind running in a circle and continually jumping high in the air. He stalked in on her and found she was defending her fawn from the attacks of a fox, trying to strike him with her feet every time he rushed at the fawn. From the marks on the ground the poor thing must have been doing this for a long time, and she was nearly exhausted. Owners of deer-forests may find they are making a mistake in preserving these animals, as some of them do.

But he also habitually kills lambs when rearing his own cubs, a thing that the fox of the Lowlands never does. With mutton at the price it now commands, there can be no forgiveness for this crime. Mr. R. Gray, in his evidence, states that they ' take a sickly lamb in preference 
102 GAME PRESERVERS AND BIRD PRESERVERS.

to a healthy one;' but is not this riding a favourite hobby rather hard? Certainly Longfellow tells us

There is no fold so well tended but one sick lamb is there.

But by what process of natural selection does the fox discover him and make him his prey? Does he hide behind a rock and carefully examine the flock on the hill-side till he discovers this unfortunate little beast, in the same way that a deer-stalker carefully examines the herd of deer with his glass until he decides which is the finest stag? Or is a fox, who could catch the stoutest wether on the hill in a few seconds if he wished to do so, supposed to chase the sheep until, after an arduous run of some duration, the sick lamb's powers give way and he falls into the jaws of the then nearly exhausted pursuer, as some people imagine the sickly grouse unable to fly as fast as the others become the prey of the falcon? But shepherds tell us that the mountain sheep never run from 
the fox or take any more notice of him than they do of the hare. They are accustomed to seeing him, and he never runs after them nor does he bark at them in that rude manner which they so dislike in the dog. When his cubs are of an age to require lamb he gets the wind of one sleeping at night beside its dam, creeps to within springing distance and leaps upon it. The mother flies into the darkness from she knows not what, calling to the lamb to follow, but beyond one pitiful cry it makes no answer, and it never follows her again.

It is these sheep calling for their lambs at night that warn the shepherds that the fox is on their hill. Should the lamb be heavier than the fox likes, or for some other reason difficult to explain, he will eat a little bit out of it and leave it and catch another. It is quite common to find two or three lambs so left on the hill in the morning - a pleasant sight for the farmer! We heard it calculated last summer that one pair of foxes had in that one season done $80 l$. 
104 GAMIE PRESERVERS AND BIRD PRESERVERS.

worth of damage, and it is not unusual to count twenty and twenty-five lambs' skulls round the cairns where they rear their young. If this cairn is discovered by either man or dog, and then left for even an hour, the old foxes will infallibly remove the cubs, generally taking them five or six miles. We know a good keeper who, unexpectedly finding a den, kept watch gallantly for nearly twelve hours until a passing shepherd came to his assistance. Two or three guns are generally necessary, as every pass must be guarded, and before morning the vixen, if giving suck, will most likely be shot. If the dog fox has ever been shot at it is almost impossible to get him, as he will, whichever way he may return, invariably make a circuit, and get the wind before approaching the cairn. After watching all night one of our keepers looking round just at daylight saw a fox coming straight towards him with a lamb in his mouth, and firing at his head, the lamb received the charge, as we found by skinning him, and the 
fox escaped. The vixen and all the cubs but one were killed on this occasion, but this fox succeeded in getting this one away and reared it himself. Both father and son, however, were shot out of another cairn five miles off, three months later, and a No. 2 shot was sticking in the leg of the old fox below the knee. He no doubt received this wound when the dead lamb saved his life.

They are easily trapped before they are a year old. We have known three caught in a trap baited with the body of one of the same litter; but if a fox has once sprung a trap he will not go near another. We got two good foxhounds from one of the established packs, and tried to run them to ground, but had no success. The country was so severe that they always ran quite away from us, and were generally out all night.

In July 1871 our head keeper was out with a terrier which bolted an old vixen and followed her about half a mile, when she turned 
106 GAME PRESERVERS AND BIRD PRESERVERS.

to bay. The dog closed with her, but getting much the worst of the fight was glad at last to run for it. The for followed him, repeatedly bringing him to bay, but the keeper hid in some tall brackens and the dog coming to him for protection, he succeeded in shooting her. She would no doubt ultimately have killed the dog, and it was the more curious her being so savage as she had no cubs with her.

Oddly enough, the same man killed another last year in nearly the same manner, but in this instance it was a young terrier bitch that bolted a large dog fox. The terrier had never seen a fox before, and probably this fox had never seen a dog. He thought her the most charming little creature he had ever met with, and they came back together most lovingly, the fox rumning first on one side of her and then on the other, swinging his brush about and looking as handsome as possible ; and she played with him, and lured him to his doom, as many a heartless 
woman has lured many a good man and true to his.

It is a curious fact that they will never kill lambs anywhere near their den. They will pass through them in all directions and go and bring others a distance of miles. Only last May we told a farmer there was a litter on his farm. He said directly, that then he should lose no lambs this year. 
108 GAME PRESERVERS AND BIRD PRESERYERS.

\section{CHAPTER X.}

THE POLECAT, THE STOAT, THE WEASEL, AND THE HEDGEHOG.

The Polecat, Stoat, and Weasel belong to the most blood-thirsty tribe of animals in the world. We write blood-thirsty, for while most other beasts of prey kill and eat an animal and are satisfied for the day, or, as is the case with the tiger, for several days, these little beasts kill and drink the blood of any number of creatures in a few hours, upon which they may once succeed in fastening their cruel teeth. They spare neither age nor sex.

The polecat, the largest, is of course the most mischievous. He ranges over miles of country. We track him in the snow high on the mountains, and along the sea-shore as well. 
POLECAT, STOAT, WEASEL, HEDGEHOG. 109

Some gentlemen think the larger hawks kill numbers of polecats. This is setting a thief to catch a thief. We would save these amateur policemen their trouble by having scarcely any for them to catch, though a few will always come into a country every year, and always by the same passes. A trap set in certain passes will produce its annual polecat almost as regularly as a tree bears its fruit.

When innocent and happy creatures are protected, and are tolerably numerous, these animals crowd to the feast from the regions where they live and breed, and which they have nearly cleared of animal life.

Catch them as you will, the cry is 'still they come.' A gentleman not many years ago purchased a large Highland property upon which Nature had certainly established her own balance, for man had not interfered within the memory of men. Eleven out of the first twelve traps his keepers put down were actually tenanted the next morning by one or other of these creatures. 
110 GAME PRESERVERS AND BIRD PRESERVERS.

Yet so ill had these animals fulfilled their part of 'game preserver,' which as one gentleman tells the Committee is their mission, that these men were out three days with the dogs before they saw a single grouse, and partridges were as nearly extinct. Now fifty brace of either bird may often be seen in a few hours in this country.

To call an animal a 'bird preserver' because he will occasionally destroy another animal which in an infinitely less degree also kills birds, seems hardly sound reasoning. Instead of describing polecats, stoats, and weasels as living upon rats we should describe them as living upon birds, hares, and rabbits; certainly all the summer months, and sometimes killing rats when pressed by hunger.

Yet another witness draws a sad picture of the loss a farmer suffered who stacked his corn in a corner of a field, hoping that these animals would take care of it, and found it nearly destroyed by rats. 
POLECAT, STOAT, WEASEL, HEDGEHOG. 111

If a farmer, instead of employing the village rat-catcher to run his ferrets through a stack occasionally, trusts that Providence, in this instance kindly inclining the balance in his favour, will send such a sufficient number of stoats and weasels as may exterminate any rats which may try to breed in it, he does not act much more wisely than if he trusts to the natural inequalities in the ground to carry off superfluous rain, instead of making drains.

One summer day we saw a turkey which was about six weeks old apparently entangled in some long grass. Going to help it, we found a weasel had it by the throat. As it could not live, we dropped it, and watched with the gun, and soon, seeing the grass move, shot its murderer.

A few weeks afterwards a servant found a large Brahmapootra hen killed by a stoat close to the house. The stoat had her also by the throat. Now, we argue, that if these acts are committed where these creatures have been 
112 GAME PRESERVERS AND BIRD PRESERVERS.

systematically destroyed for years and years, what bird which lives or breeds principally on the ground would be safe, if, as some naturalists wish and advise, they were always preserved?

And one 'cruel' keeper, the Rev. Mr. Morris tells us, had actually destroyed fifty-four in a short time. If they were so numerous, was not it time for man to interfere?

But these gentlemen's arguments are unintelligible to us. They wish to preserve birds, they say; but they seem much more anxious in reality to preserve birds' destroyers.

Let us furnish a stoat with a diary, and with the power of telling us how he passes a summer day, and then read what he will probably have written :-

'Slept rather heavily, having drunk too much hen-pheasants' blood the evening before,

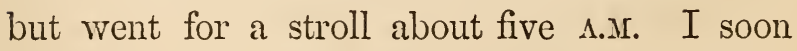
found a yellow-hammer's nest, but, jumping a little too far, just missed the old hen. However, I sucked her eggs. Shortly afterwards I 
POLECAT, STOAT, WEASEL, HEDGEHOG. 113

winded something in a low old thorn tree, and climbing up found a nest with four fine young blackbirds in it, and I made a nice light breakfast of their blood and brains. How the old birds did. scream, and what a fuss they made about it! Perhaps they will remember to build higher another season. I then made a neat stalk and killed a skylark, and as the sun was getting high thought of retiring, when I came on the fresh track of a hare. I knew her form would be close by, so followed it in breathless silence. Sure enough she was sleeping on the side of an old bank. Getting well above her Ileaped lightly on to her back, and my teeth were fast in her neck before she was fairly awake. Then how the stupid creature screamed and struggled! Just as if it was of any use! I suppose she was thinking of her little ones, for she was giving suck I afterwards noticed. However, I left her quiet enough in about ten minutes. Being rather tired, I had a long and refreshing sleep under the root of an old tree, 
114 GAME PRESERVERS AND BIRD PRESERVERS.

but waking thirsty about three o'clock, went down to a little stream and had a drink. Two ladies were sketching the old bridge, and I played about opposite them for a little while, and heard them admire my graceful movements, and wonder how any man could be barbarous enough to set a trap for such an interesting creature.

'Had another long sleep and a pleasant stroll in the evening, but had not much sport, a nice covey of partridges giving me my supper and a quarter of an hour's amusement. The old birds kept fluttering under my nose, apparently both lame and broken-winged, but I had been served that trick before, so I only laughed at them, and managed to chop eight of the young ones. Then I retired for the night, hoping for as happy a day to-morrow.'

Can any of this 'interesting creature's' friends state that, gifted as he is with keen powers of scent and an untiring love of hunting, combining the patience of the hound with the 
POLECAT, STOAT, WEASEL, HEDGEHOG. 115

cunning of the cat, he is not likely to meet with just the creatures we have mentioned in a summer's day? Or will they say, yes, he will inevitably meet with them, but he will only admire them, and perhaps play with them a little? and then continue his lawful occupation of hunting and destroying rats.

But look at his first cousin the ferret. Rear him on bread and milk, and never let him see a live creature until he is a year old. Then let him find his way one night into a coop where there are twenty fowls, and will one be alive in the morning?

We should think any humane person would be solry to see one of these creatures on his grounds, and would be glad to hear it had been destroyed.

The helgehog is the last wild beast on our list-the 'hypocritical hedgehog', as Mr. Knox calls him, and 'the most insatiable of all ovivorous British quadrupeds,' whatever his 
116 GAME PRESERYERS AND BIRD PRESERVERS.

well-meaning and amiable friencls may say to the contrary.

In innumerable instances this little beast has been detected while destroying eggs and young birds. Asleep all day, never seen by man un-. less a dog hunts him out of a hedgerow, he is busy and active enough all night. Can anyone doubt that he is continually finding nests, or do they believe he ever passes an egg without eating it?

He has probably no enemy but man, and if man did not reduce his numbers he would do incalculable mischief. Our friends the birds will catch all the insects he is supposed to destroy, and we will most certainly do without him as far as possible, hoping to see them much more numerous in his place. 


\section{CHAPTER XI.}

THE RAT AND THE CAT.

THE rat is perhaps the worst pest we have to contend against in the present day, and one of the worst injuries he has done us is in bringing upon us his supposed antidote, the cat. $\mathrm{He}$ is so clearly a parasite on man, and man has so abundantly supplied him with food and a warm and comfortable habitation that his numbers have increased until he is far beyond the control of his natural enemies. We can fancy the stoat and weasel, with a little assistance from the owl, keeping down the numbers of our old English water rat, or the black rat as he existed a thousand years ago, but they are powerless against the grey or Hanoverian rat. Can we fancy stoats and weasels 
118 GAME PRESERVERS AND BIRD PRESERTERS.

following them up the Paris sewers, for instance?

One or two gentlemen seem to think that rats have increased for want of large havks to kill them. Why, these birds would have to be sufficiently numerous to darken the air to be of the least use. And, as Mr. R. Gray states, 'rats are not exposed to hawks' attacks.' They are nocturnal in their habits for one reason, and while it is comparatively rare to find a grey rat one hundred yards from a house it is still rarer to find one of the larger hawks so near to man's habitation.

We should have been inclined to hazard the opinion that our four largest birds of prey, the eagle, the falcon, the buzzard, and the hen harrier, have not yet seen a house rat since the creation, although we have known the two last named hawks come near enough to the lonely cottages of the Highland shepherds to carry off their hens in winter. But Mr. W. C. Angus says ' he has opened the stomachs of hundreds 
of hawks and found the remains of weasels, rats, and moles.' Being further questioned, he says 'he has found weasels, rats, and moles in the stomach of the golden eagle and the peregrine falcon.' Such a statement seems calculated to mislead people into the idea that rats are the habitual food of these birds. Yet we are sure for every time that Mr. Angus found fur in a falcon's stomach he has five hundred times found feathers. We never once saw fur round their nests. An occasional instance proves nothing. A bird may have been wounded or half starved.

If an alderman were shipwrecked on an uninhabited island he would probably live upon the contents of a cask of biscuits which might be washed ashore. But the scientific gentleman among a party of savages, who might examine him after his friends who happened to land on that island had killed him for their supper, would, we know, arrive at an erroneous conclusion if he entered it in his note-books as 
120 GAME PRESERVERS AND BIRD PRESERVERS.

a fact that the animal ' alderman' lived entirely on dry biscuit.

Yet these statements may give some farmers the impression that game preservers encourage rats. They are their sworn enemies, and though it is not a keeper's business to follow the rats and hunt them out of a farmer's ricks and barns, when they in the summer months venture out into the hedgerows, he always sees that they are destroyed as far as is possible.

A rat eats and kills everything a man does not want eaten or killed. He does those things he ought not to do, and doubtless leaves undone other things. We must study how to destroy him, for man lives as much by destroying the creatures which injure him as by encouraging those which are useful to him. If rat-catching is not strictly one of the learned professions, still no stupid man ever shone in it, and a good rat-catcher is a blessing to his parish. If we had many sons to bring out in the world 
we are not sure we would not bring one of them up to this profession. There is a subdued excitement about rat-hunting which is not unpleasant. We think we should prefer it to reading for the law, for instance.

As bird preservers we must kill rats, for they eat every egg and kill every bird they can get at. The rat asphyxiator seems a splendid invention, and much as we fear and hate poison it is sometimes the only remedy. But people are so fearfully careless. We lost the best retriever we ever owned or saw through a friend putting her into an outhouse where strychnine had been laid a month previously for rats. We knew some phosphoric paste spread on some bread and butter and afterwards accidentally thrown out, and eaten by a terrier. The owner saw the dog eat the poison and gave him a violent emetic and saved him. But a brood of ducks ate the poison after the dog had brought it up, and were all dead the next morning, and oddly enough several rats eat the dead ducks 
and were found lying dead round them. This happened to the head forester on our shooting manor in 1870. But rats must be killed in the winter when they are driven into our houses, and before the next breeding season. Let men lie awake at night and invent all possible means of destroying them. Any means are better than depending on cats. The remedy is then worse than the disease; while to depend upon golden eagles and peregrine falcons becoming sufficiently numerous to habitually fly round our barns and ricks and kill our rats for us, will be, we fear, to lean upon a broken reed.

We must encourage the rat-catcher, and we would pay him on the same principle upon which the Emperors of China used, we believe, to pay their physicians. These gentlemen had large incomes as long as he continued in good health, but their pay stopped directly he was unwell, and their heads were all cut off on the day on which he died, no questions being asked, and 
no excuses listened to. A man cannot be expected to wish for the extermination of an animal by whose presence on our farms he gets his living. He should have something handsome a year if we never saw a rat, half this if a few appeared until they disappeared again, and nothing, and we would employ some one else, if they became troublesome.

The wild cat is, we believe, becoming rather more numerous than it used to be owing to its being allowed to breed undisturbed in our deerforests. We killed two which came close to the house and carried off our tame ducks.

But the house cat is nearly as destructive. How any person can pretend to care for birds, and yet harbour and encourage cats is one of those enigmas we cannot understand. What should we think of a superior race of beings who pretended great affection for us, and passed laws for our protection, yet who each of them kept one or two tame tigers, giving them their liberty with the certain knowledge that 
124 GAME PRESERVERS AND BIRD PRESERVERS.

they were destroying us, our wives, and children every day?

We tax the useful dog. Why cannot we have a cat tax ? It would do more to increase the numbers of our birds than any law. Do cats give birds a close time from March to August? They render night hideous to man in towns, and day and night terrible to birds in the country.

Our gardens and pleasure-grounds, which might be paradise to our birds, are shunned on account of their presence. What would the Garden of Eden have been to Adam if there were a couple of lions in it? We may be sure that after they were brought to him to name they were taken outside again directly, and that the gate was shut securely. Several gentlemen mention cats to the Committee, and $\mathrm{Mr}$. Vivian, Mr. Champion Russell, and Mr. Johns all tell us the only way in which cats ought to be kept in the summer. After April 1st their cats are chained. A ring at the end of the 
chain runs along a wire, stretched from one end of the garden to the other. They have a little house at each end of the wire, and they walk up and down and defend any seeds or fruits which it may be desirable to defend from birds.

- Mr. Vivian pathetically laments 'he cannot. more freely kill his neighbours' cats.' We heartily sympathise with him.

Many ladies are subscribers to the Society for the Prevention of Cruelty to Animals yet keep cats themselves. Do they realise that nearly every day in the summer these beasts kill a bird, and the little ones are left to starve in their nests?

We have heard that in New Zealand already a curious ground parrot has become nearly extinct owing to the numbers killed by the settlers' cats.

Mice are easily caught in traps, and who ever knew a farm kept clear of rats by cats? We have often thought the more cats the more rats. 
126 GAME PRESERYERS AND BIRD PRESERVERS.

All the summer months cats are too busy killing birds to meddle with them. And they bite and birds do not. Few would believe the distance cats travel. We have met them three miles from home. In the Highlands we would not let a cottage or croft except on the condition that no cats were kept, if we paid a few shillings a year extra.

These shepherds' cats all get their own living, and they kill every partridge and every grouse which tries to breed within a mile of their houses.

Grouse constantly come into the peat bogs to breed, but before they have been there a month one or other bird is sure to be taken.

One gentleman thinks it most hard ' that cats cannot visit his neighbours' woods without being killed or maimed by the keepers.' Does he ever ask himself what these cats go to the woods for? Certainly not to catch rats and mice, which are far more numerous close at home. They go to kill our birds which we pass laws to protect, 
but any creature which will kill a bird finds a friend and advocate in the Rev. Mr. Morris. And they will breed in our woods. Are they to have a close time? And may we thin their numbers afterwards if 'inconveniently numerous?' And if so how?

We wish to kill them in the most humane way possible, though a cat six or eight hours in a trap probably does not suffer so much as she has made some other poor creature suffer on nearly every day of her wicked life.

Let their friends invent a trap which will annihilate them the moment they touch it, or a poison so delicious that they cannot resist it, and so subtle that it will send them directly into a sweet sound sleep, from which they will never waken, and we will gladly use these things. Until they do this, we will kill them as best we can, because we love birds better than we love them. When natural history begins to be really taught in our schools, and people learn to know the value of birds and the worthless 
128 GAME PRESERVERS AND BIRD PRESERVERS. ness of cats, any cat found at large in the summer months will be destroyed as a matter of course.

At the present time some well-meaning but, we think, not very wise individuals represent a man as a sort of barbarian if he kills one of these cruel, destructive beasts. 


\section{CHAPTER XII.}

THE GROUSE.

The red grouse is about the best game bird in the whole world, and deserves all the care we can bestow upon him. No agriculturist, however opposed to game generally, has ever pretended that the grouse does him any injury, while his presence on our hills adds to the amusement or to the income of our landowners in a quite extraordinary manner. A proprietor may calculate on receiving about 1l. a brace for all the grouse his land will produce, if they are only found in sufficient numbers to make it worth while to pursue them at all; but this makes all the difference.

There are always gentlemen to be found willing to pay $100 l$. for a month's run in our 
130 GAME PRESERVERS AND BIRD PRESERVERS.

beautiful Highlands with the certainty of bagging at the least 100 brace of grouse, and a moor which produces 500 brace in a season, particularly with a mixture of other game, will command 500l. a year. But grouse shooting where there are no grouse is the play of Hamlet with the part of Hamlet left out, although men can enjoy themselves without making heavy bags. We think there is more pleasure in bringing home twenty-five brace with the help of excellent dogs, by using straight powder, and really walking for some six or seven hours, killing perhaps half of what we see, than in bagging four times that number where the birds are gathered together so thick that the dogs are pointing before they can canter one hundred yards. But men and dogs will not work to kill an occasional old cock bird or to murder two or three brace of unfortunate barren birds. After the second or third day some excuse is made. Fishing or boating is proposed. The work is too hard 
where there is so little seen to keep up the excitement.

There are no class of men whose opinions we find it so hard to understand as those who are fond of writing to the papers condemning as 'cruel' all who make large bags of game. That men should object to find pleasure in a pursuit which entails the shedding of blood we can quite understand; but these gentlemen all boast that they are sportsmen themselves, only of the good old manly school they think. They never hire a moor, partly because they object to pay the rent. They consider keepers useless and still more cruel than their employers. We will follow for one day two of these gentlemen who are making an ornithological and sporting tour in August. They have a useful dog with them who never goes fast enough to tire himself, so he gets through a good many hours after a fashion. They easily get leave to have a day's shooting on one of the large islands in the Hebrides, as the 
132 GAME PRESERVERS AND BIRD PRESERVERS.

owner well knows there is but little to shoot on it. They are in luck to-day, however, and before long find a brace of grouse and bag them, and presently another brace, and these also fall. One of them observes it must have been a bad breeding season. But these birds had had their eggs taken by the hoodie crow whose nest they had seen in the birch wood they had come through. The dog stands again after they get on to higher ground, and four birds rise and they kill them all, for they can shoot a little if birds rise near them and they are not flurried. This is delightful, but these are the remains of a fine brood of ten. The falcon, who breeds on the opposite island, found them out a month ago and has reduced their numbers. They both miss a snipe, and then each kills a hare, but they only see and bag one more brace of grouse. The ravens, whose voices they so admired as they rose from the carcase of a dead sheep, had swallowed these poor birds' 
young ones when they were a week old. And these gentlemen return home delighted with their sport. As they will often tell their friends, they shot at thirteen head and bagged twelve. How different to the barbarous sportsmen who, they will hear, on the same day, a few miles off, bagged thirty brace of grouse. Yet they have done a very cruel action, and have interfered with the balance of Nature with a vengeance, for those few poor grouse happened to be literally all that were left alive in that part of the country, and it will be many a day before the cheerful crow of the grouse cock will be heard again on those hills.

One gentleman, being asked by Mr. Sturt, 'Are you a game preserver?' replies, 'Yes.' Being asked if he preserves birds of prey in the next question, he replies, 'Yes, everything: eagles, peregrine falcons, and merlins.'

We think this gentleman would have answered the first question more correctly if he had replied, 'No, I am a game destroyer. I 
134 GAME PRESERVERS AND BIRD PRESERVERS.

hate game birds, and kill them when I can get near them in the autumn myself, and welcome on my land any creatures which will tear them to pieces all the rest of the year, or, if they can only swallow their eggs and newly-hatched young, like the raven, I am delighted to see them.'

Yet, thanks to an entirely different policy having been adopted probably for the last twenty years on the property he shoots over, and to his neighbours following a different policy, this gentleman has still a good deal of game on his ground, in the same way that Mr. Waterton, while doing his best to encourage all the creatures which destroy that triumph of acclimatisation, the pheasant, could always, thanks to his neighbours, boast that he had some in his park and on his table.

When we take to preserving their enemies we will certainly cease to shoot them ourselves, and will carry a walking-stick instead of a 
breech-loader when we visit them in their mountain homes.

It is not in the number of birds which a man kills in a day that the cruelty of shooting consists, but in the fact whether he has or has not previously given them such protection from their numerous enemies as to justify him in killing this number. If he does not protect them, he cannot kill a single game bird without throwing his weight into the scale against a persecuted, harmless race which can scarcely maintain their existence as it is. No bird requires help from man more than the grouse, and their preservation is well understood in many parts of Scotland and in Yorkshire, where that national loss, a grouse killed in the spring months, is never known; but in Argyllshire their remains are scattered all through the hills, and landowners wonder their land is not worth shooting over; but as they know it never has been, they are contented that it never should be. Yet wherever 
136 GAME PRESERVERS AND BIRD PRESERVERS.

there is heather, whether one thousand feet above the sea, or on great boggy flats almost below the sea level, the landowners have only themselves to thank for lack of grouse which, if not as numerous as in Perthshire, might be still numerous enough to give first-rate sport.

Many have no keepers. The shepherds have a little something a head for any crows they may catch. Others, perhaps, have one man to 30,000 acres, and though there are plenty of excellent men among these, not a few literally never set foot on the moors from the day the sportsmen cease to shoot in October until about a fortnight before his return in August. Then they go out a little with the dogs, and appear full of information about where the birds are. They trap the weasels round the stone dykes, and stalk the crows on the seashore. But they never dream of following the falcon to her eyrie, perhaps five miles off, and watching day by day in March winds and rain till they kill her; or of building a hiding-place, and waiting 
for the hen harriers, which come each year and breed on their ground. These large hawks kill two-thirds of the grouse which are trying to breed in the country, and the keepers know no more about what they are doing than the lessee at his club in London.

The grouse require what the Committee would give by law to all sorts of little birds' a close time, when they can breed in peace' in the spring.

And they require food and a home, and this the heather would give them; but as if man's only aim was to drive them out of the country, he burns this over their heads.

Sheep and grouse require exactly the same management with heather-a constant succession of young heather, secured by judicious burning. This is perfectly understood in most parts of Scotland, and the heather is burnt in strips. In Argyllshire there is a clause in the farmers' leases about burning a tenth of the heather, but it is a dead letter. Each shepherd 
burns what the wind and a box of lucifers will enable him to burn. Whole tracts of thirty acres are burnt down till they would not shelter a lark.

And again, with a rainfall of nearly 100 inches per annum, draining, even open surface draining, is for miles and miles not attempted; and though grouse will live and thrive in actual bogs, where there are a constant succession of hillocks and ridges always dry, they will not stay on a dead level, to be for a week at a time ankle deep in water. They leave, and finding land in a condition more worthy of the nineteenth century they never return.

Were the respectable barbarians who owned many of these Western Highlands estates a thousand years ago, to return to them to-morrow, they could almost fancy they had only been asleep for a week. Nothing has been done, except to cut down most of the oak and birch woods they used to hunt the roe deer in, not a tree being planted in their place, 
not a drain cut, not only no roads or pony paths, but not even footpaths made through the mountain, and in a country where the very shepherds are constantly lost in the mist. Estates change hands, but years pass by and nothing is done. It is the very land of the 'lotos-eaters,' where it is 'always afternoon,' and this within twenty-four hours' journey of London.

The grouse disease has not yet appeared in the Western Highlands, and this is an inestimable advantage, and there the scenery is as fine as any in Scotland. The grouse also do not pack, and, except in very stormy weather, always lay well to dogs. We have known one gun bag twenty and a half brace in the middle of November in a few hours, and a man who has done this over two brace of quite firstrate dogs has perhaps had as good sport as dog and gun can give.

If the proprietors would for seven years see that the heather was burnt under the direc- 
140 GAME PRESERVERS AND BIRD PRESERVERS.

tion of some confidential person, or if they gave their tenants notice that their leases would not be renewed if they did not manage to burn the heather as it is burnt in other parts of Scotland, it would treble the stock of grouse.

And let them take measures to find out if the grouse on their estates are allowed to live to breed. It does not follow that they are allowed because a man who is called a gamekeeper lives on some part of the estate.

As a single instance of the difference this makes, we may mention that we knew there were more than twenty brace in March on the beat the falcons cleared for us in 1871. Yet we found but fifteen of these bircls alive in August, and with only one late-hatched brood among them. To effect this ruin these hawks had only in the four months to kill twentyfive birds - about three a month to each hawk. There were neither crows nor any other vermin in that part of the country. Had these twenty brace bred in peace we should 
have found at least sixty brace on the day we shot over that ground, and probably have bagged thirty brace out of them.

Grouse will occasionally rear ten young ones, but they average from three to six young birds to each pair, according to the season. It is very rare for them not to bring up even one or two in the worst seasons. When barren braces are met with it is nearly always caused by their first mates having been killed or their eggs having been eaten. Yet when grouse have not been numerous enough to make it worth while for gentlemen to go after them, we have known the keepers often sent out to shoot these barren braces for not breeding, under the idea that they must be very old birds.

As a proof that fair sport may be obtained where ground has always been considered as not worth shooting over, we shot over a beat on August 20, 1869, and did not in the whole day even see a single grouse, but in $\mathbf{1 8 7 3}$ one gun bagged eighteen brace in a few hours on that same beat. 
142 GAME PRESERVERS AND BIRD PRESERVERS.

But to make fair bags in the Western Highlands good fast dogs are indispensable. They must range far and wide, or you will not find half the birds. We always took out six in the hot weather, and never let a brace run for more than an hour at a time. When a man tells us that his dogs are never tired, we know that they must go at the pace of a tired dog all day. There is as much difference in the pleasure of shooting to these fast, brilliant dogs, instead of to the slow, old-fashioned potterers, as there is between riding a cob or a thoroughbred hack. The best dogs we have seen were a first cross between the Lavrack and Gordon breeds. Then there is such a variety of game in this part of Scotland, that from August till February, weather permitting, dogs may be finding game of some sort every day in the week. The extent of many of these estates is so great that we never, unless the weather was most unfavourable the first time, shot over a grouse-beat twice in one season; so, if we could perfectly protect 
them, the grouse had a happy life three hundred and sixty four days in the year.

Woodcock, though not so numerous as in Ireland, often give good sport. On the evening of the fourth day's frost we once had fifty-eight on the hall table, besides other game, and we knew a man fire 150 shots at them on another occasion in four days.

But it is the presence of grouse on the ground which will regulate the amount of shooting rental which an estate will command; and we repeat, if a man has heather and has not grouse on his land it is his own fault. 
144 GAME PRESERVERS AND BIRD PRESERVERS.

\section{CHAPTER XIII.}

THE BLACK GROUSE AND THE PARTRIDGE.

Nothing has surprised us more than to find that that fine bird the black grouse is literally not mentioned in all this evidence. Not a naturalist has a word to say for him, while the disappearance of such birds as the siskin or garden warbler is constantly regretted, and we ransack other countries and import and try to acclimatise quails and let this splendid creature become extinct. There can be no reason why he should not be fairly numerous in at least half our English counties and in many parts of Ireland. Heather is not a necessary of life to him. Give him a rushy grass field to be hatched and reared in, a corn-field to spend the autumn evenings upon, and a snug birch wood where 
THE BLACK GROUSE AND THE PARTRIDGE. 145

he can find food and shelter in the winter days, and he is content. We should like to see a three years' jubilee given to these birds in the English counties where they are still to be met with. There were a few near Aldershot in 1862, but the young broods were all shot down whenever they were found. It seems most unfair to commence shooting them on August 20. They are hatched on the same date as the pheasant and do not acquire their full size or perfect plumage any sooner, and the grace they get by ceasing to shoot them on December 10 is of little use to them.

Perhaps their management is better understood and they are more numerous in Dumfriesshire than in most places. In October, when they are fine strong birds, a party sometimes kill 200 brace in a week in that county. We love to see them, particularly in the spring; and to creep near a party of old cocks, and watch them strutting about like turkey-cocks with their wings and tails spread out, is most amusing. 
146 GAIIE PRESERVBRS AND BIRD PRESERVERS.

We know that the English climate suits these birds, and that they can hold their own against their natural enemies as well as the partridges, for they live through the winter in the Highlands without the least help from man. There is but one reason, and an all-sufficient one, why they have nearly disappeared. Because men shoot them down before they are much more than half grown whenever they meet with them. Mr. Knox strongly advocated their introduction into Ireland some years ago. We never heard if this had been done, but there cannot be any great difficulty in doing so, as they are more easily reared tame than pheasants, being much less susceptible to cold and damp, and thriving on exactly the same food, particularly ants' eggs. As they are polygamous they ought to lay in confinement, but we cannot state if they will do this, having three years in succession been unfortunate with ours. In the first season rats carried off eight when they were about six weeks old. The next year we reared nine- 
THE BLACK GROUSE AND THE PARTRIDGE. 147

teen, and the cocks were acquiring their black feathers in the beginning of August, when a cat found them out, and having reduced their numbers to thirteen, these were for security put into a large open wire pheasantry, which was removed on to fresh ground on purpose. They all sickened and died in about three weeks; so it would appear they will not bear confinement, when young at any rate, although an old black cock, who, to escape from a falcon, found his way into our kitchen by smashing a pane of glass, has lived many months happily in a pheasantry. Their foster-brothers, some pheasants confined at the same time and in the same place, throve well. This year we meant to leave them at liberty until November; but some wild black game unexpectedly joined them early in October and decoyed ours away. We have but little doubt that they could be kept when their management was understood, and each hen would probably lay about twenty eggs. They would be a charming addition to our game birds in 
148 GAME PRESERVERS AND BIRD PRESERVERS.

many parts of England where they are now never seen.

The partridge is perhaps as numerous in many parts of England as it well can be; but a sad change has come over it. The change in our system of cultivation has changed its habits, and it no longer gives us the sport with dogs which used to constitute the charm of partridge shooting. This cannot possibly be helped, and we must accept the situation and make the best of it.

Partridges must be driven in most of our counties, and let those who ridicule the sport come and show us how to kill them. There is no such difficult shooting, and more shots are fired with less result at driven partridges than at any other game in any part of the world.

A rery great mistake, which several gentlemen make, we believe, is that it is an injury to a breed of birds to kill the old birds.

The French, who quite eclipse us in making 
THE BLACK GROUSE AND THE PARTRIDGE. 149

poultry pay, never let a domestic hen live over sixteen months. They lay less eggs every year after the first, and get tougher and of less value for the table. We find it answer well to kill all our turkey hens the second year. The quantity of grouse and partridge has notably increased on many moors and manors since driving was introduced, entirely owing to the old birds being so generally shot.

It is well known that if a moor or manor is fully stocked, and is not shot over at all, at the end of two or three years the birds will have very much decreased in numbers. This is owing to the old birds driving away the young ones and not breeding themselves. It is difficult to prove, but we doubt if a cock grouse or partridge rears a brood after the second or third year. He makes vows of eternal devotion, which last a fortnight, to first one hen and then another. These hens, being forsaken, forsake their eggs, for birds that pair will rarely hatch and rear a brood alone. Old cock grouse are 
150 GAME PRESERVERS AND BIRD PRESERVERS.

killed as vermin by many people who know what they are about.

Gentlemen who do not want to shoot their partridges until the end of September when they return from Scotland, would, we believe, nearly double their bag if they had all the first nests taken and reared under hens. The expense is small, as these birds so soon get their own living. These tame reared birds would hardly have joined the wild birds, and though they would be difficult enough to get near, would scarcely behave as disgracefully as they so generally do now; and the wild birds would nearly all lay again, and their young, though quite strong by October 1 , would not be so wild as their first hatch. Partridges soon get shy. We remember a lot of forty some years ago which we thought we could bag any day we pleased. But the first shot altered matters, and we never bagged a bird till they came out of a wood one day in December.

Partridges and all game birds travel and fly 
THE BLACK GROCSE AND THE PAR'TRIDGE. 151

distances which few would believe. Two years in succession a large number were reared in the Lewes from imported eggs. They were constantly seen in the country all through the winter ; but in pairing time each year the whole of them left the island, and the nearest land is forty miles off.

In the Highlands they give capital sport with dogs in the winter, where they are cared for and protected. They are extinct on many estates. Every patch of cultivation will be frequented by at least a pair, and these will rear large coveys. But every cultivated field is somewhere near a house-possibly a lonely shepherd's house,-and one or two cats are kept in each house. These as regularly kill one or both of every pair of partridges which try to breed on these fields, as the falcons break up every pair of grouse. By stopping the depredations of these beasts we got up a nice head of partridges in every direction. On the last five days of January we once bagged ninety, all 
152 GAME PRESERVERS AND BIRD PRESERVERS.

over dogs. Though wild, and seldom rising within thirty yards, they were still to be got when driven into the heather, and they made a nice addition to the winter shooting.

We seldom shot a bird till November. Partridges require protection nearly as much as grouse. They do not seem to be plentiful on the Continent generally, and though they and pheasants might be eaten in millions by men in most parts of Europe, their management is so little understood that they are comparaticely rare.

It is perhaps also caused a little by the idea that if these birds are preserved hares and rabbits must also be preserved, and these do serious damage to the farmer and injure the cause of game-preserving all over the world.

The partridge loves cultivated land. In Europe, Asia, and Africa he finds it out and comes to it, and instead of being encouraged is generally exterminated. Yet he is a friend to the farmer, eating millions of the most destruc- 
THE BLACK GROUSE AND THE PARTRIDGE. 153

tive insects. Perhaps England is the only country in the world where they are prosperous and happy. . In other countries, if man does not destroy them himself in their breeding season, he allows their enemies to do so.

Through the whole of India, from where we left the railway, seventy miles from Bombay, to where we joined it three years later, two hundred miles from Calcutta, we never found the beautiful painted partridge or the common partridge at all numerous, although they scarcely ever died by the hand of man.

The grandsons of our present merchant princes will, no doubt, preserve large tracks in India, for sport the Anglo-Saxon must and will have, and they will bag 150 brace of peacocks a day and send them home in ice by the Persian railway. We should like nothing better than to preserve certain tracks of country we remember. Visiting our traps would require caution-a young tiger in one, an hyæna in the other,-and the services of the real tiger 
154 GAME PRESERVERS AND BIRD PRESERVERS.

terrier would be required. A friend of ours brought home a curious little nondescript dog, and when asked what it was, he always said, ' it was the real tiger terrier of Central India,' and it did not seem to occur to one person in ten who asked the question, how ridiculous the idea was that such a little creature could be used against tigers.

But it is at the Cape of Good Hope also that some little knowledge of bird preserving is really required, for that fine francolin called the red-winged partridge, nearly as large as a grouse, and as well behaved before dogs, is fast disappearing from hundreds of miles of country. In very many places, where twenty years ago ten and twelve brace could be bagged at the beginning of the season, they are now never seen. Ammunition was scarce, and the farmers used to reserve theirs for bucks, never wasting it on birds; and they had no dogs which would find these partridges, which lie very close. Now, officers have imported so many that there is 
THE BLACK GROUSE AND THE PARTRIDGE. 155

tolerable good blood all over the country, and the farmers and their friends from the towns kill all they can. But they grudge a charge of powder to shoot the great hawks which come round, even following the dogs and catching the birds before their eyes. They have joined the francolin's enemies and turned the balance, and the extinction of these birds is the result.

They come to all the fields where the Kaffirs grow their Indian corn, and would breed in them, but the boys kill them all. These savages all throw sticks with great precision, and each man or boy carries three or four. We have seen them kill the smallest birds on the wing; and when they have marked a partridge into some long grass, a few of them surround him, and he has no more chance of escape than if they were armed with guns.

The red-wing and the grey-wing partridge, a smaller bird, but faster on the wing (Francolinus Levantillii, and Francolinus Afer), are rapidly retiring before man, instead of prospering 
156 GAME PRESERVERS AND BIRD PRESERVERS.

through his cultivation of the soil, and they take refuge on the grassy ridges of the mountain ranges. Here, miles from either rocks or trees, which shelter their enemies, they breed in peace, and a couple of guns, if fortunate enough to have first-rate dogs with them, can bag from twenty to thirty brace in a day. This is in every respect as enjoyable sport as grouseshooting.

The mountain scenery reminds one of Scotland; only we have the certainty of fine weather, and firm turf, on which a horse can gallop under our feet.

We wonder none of the farmers in South Africa have taken to preserving; so many birds would thrive in that lovely climate. Yet pheasants are not even introduced yet, unless there are a few near Cape Town, and the wild guinea-fowl, and another francolin ( $F$. clamator), which loves the woods, would soon increase immensely.

The guinea-fowl, however, does great injury 
THE BLACK GROUSE AND THE PARTRIDGE. 157

to many crops, while the partridge never does any harm, and well repays a little assistance.

To take an instance, we will only suppose a man, in any part of the world, has ten pair on his ground in the spring. He leaves them to take care of themselves, not interfering with the balance of Nature. A prowling cat kills five or six. A crow robs three of their nests, and a sparrow-hawk and a weasel so thin the numbers of the others that there are but twenty again left alive by next spring. But in the winter this man has learnt a little practical natural history, and he takes measures to destroy four creatures - a cat, a crow, a hawk, and a weasel. His partridges enjoy a peaceful, prosperous summer, and rear an average of ten birds to each pair, and he is able in the autumn to put one hundred delicious birds on his table which have not cost him a penny. We think he has acted rationally. 
158 GAME PRESERVERS AND BIRD PRESERVERS

\section{CHAPTER XIV.}

\section{THE PHEASANT.}

THe pheasants form such a splendid addition to our list of British birds that we cannot understand how any gentleman who is fond of birds can be satisfied if he has not a considerable number on his estate. They might easily be twenty times as numerous as they are, when they would be sold at a price that would put them within reach of hundreds who now nerer taste them; but the unsatisfactory state of the law is no doubt one reason why they are not encouraged in many places as they deserve to be. We can never see any reason why all birds should not be made the property of the owner or occupier of the land, as much as his cows and pigs. The Game Laws are called a relic of feudal times, but it is the extraordinary 
idea which some people hold that, because certain birds which do not belong to them, happen to be rather difficult to catch, as well as excellent eating, they may come and catch them and carry them off, which is really a relic of very old times. Of times when

Deeds were many and men were few.

When

Wild in woods the noble sarage ran.

A North American Indian, who came and settled in one of our midland counties, and saw flocks of turkeys feeding in the stubbles, would think it an intolerable injustice that he might not kill and eat these birds when he pleased; and our own noble savages think it equally hard that they may not kill and sell our pheasants whenever they require either amusement combined with excitement, or a little money, and they find plenty of people, who ought to know better, to pity them if they are punished for doing this. A gentleman may have turkeys, fowls, and pheasants roosting in the trees round his house. If a stranger takes 
160 GAME PRESERVERS AND BIRD PRESERVER

either of the first-named birds he is a contemptible thief, but though the pheasant has cost as much to rear as the other birds, if he takes him he is only a poacher-rather an interesting character, and to be screened from punishment if possible.

We know a farmer in Warwickshire who owns some land which runs between two estates, and the owners of both these estates preserve, and one of them rears a large number of pheasants, and this man scatters a little food on his side of the hedge, fills the hedge with traps: and catches scores of his neighbour's birds. Yet, if he were to catch his neighbour's hens in this manner he would be thought a thief.

If pheasants were much more generally reared than they are, an Englishman's natural respect for property and sense of justice would soon set this right, and it is a pity there should be a single cover in the whole country without a nice sprinkling of these birds; and every 
farmer's daughter, where he has the right of shooting, ought to rear him fifty or a hundred birds every year, if he has only ten acres of cover. They are a beautiful ornament to our parks and pleasure-grounds; and a never-tiring amusement on every winter's morning used to be to watch a party of all sorts, gold, silver, pied, Chinese, and ring-necked, which lived in perfect freedom, and assembled regularly for their breakfast within thirty yards of our windows. The gold pheasants used to arrive, escorting their hens with great pomp and ceremony. There is no vainer bird than a gold 'pheasant, and the way he is always displaying his beautiful neck-feathers to the hen is most amusing. Then a party of cocks would come from some distance, with a great amount of crowing and fluttering of wings. These were all-important people-heavy swells, in fact. Then a silver cock would stroll calmly up. $\mathrm{He}$ is a most aristocratic bird, but often gave offence to the others, and was probably soon engaged in an 
162 GAME PRESERVERS AND BIRD PRESERVERS.

affair of honour with a gentleman with a ring round his neck. The wilder birds would arrive quietly on foot. These were the poor relations, and they did not seem quite sure of their welcome; but there would be more than fifty by the time the keeper appeared with the corn, when a few old favourites would run to his feet, the greater number disappearing in great pretended alarm, only to return in a few seconds. We feared no poachers but cats and stoats, and except on the other side of a loch two miles wide no guns but our own were ever fired within eight miles in every direction.

If pheasants are to appear on our tables in any number-and we fancy few really wish to banish them-they must be reared under domestic hens, and then left in a state of freedom. When fit to kill, whether they shall all be driven into nets and have their necks twisted, or whether they shall be shot at, when at least thirty per cent. will probably escape, is surely for the owner to decide. If he shoots them he 
will be called cruel by certain newspaper writers. If the writer were a pheasant, would he really prefer the netting process, and the impossibility of escape? We fancy not. We know if we were to be hatched as a pheasant, we should be unfilial enough to hope sincerely that our poor mother might have her nest robbed, and we might be hatched by a hen. It is curious what bad mothers they are. While we have often known a partridge rear her whole seventeen, a pheasant in a rough country will scarcely on an average rear more than three. We saw one cross a wide drain, and go on with two which had crossed where it was narrow, leaving six to lie if we had not rescued them.

Two or three gentlemen tell the Committee that Mr. Waterton had plenty of pheasants. If he put down food, and never disturbed his covers, a certain number of his neighbours' birds would find their way there, no doubt; but if his woods were the refuge for all the stray cats and stoats in the country, and if his park was full 
164 GAME PRESERYERS AND BIRD PRESERYERS.

of crows, magpies, and jays, we can scarcely believe that any number of pheasants were reared on his ground, for you cannot both ' eat your cake and have it.'

A non-sporting visitor, taken out in the evening to see thirty or forty pheasants feeding round the woods, would come away with the idea that they were very numerous, although he had probably seen every bird on the property; and as the keepers trapped three or four every week, and they always appeared on the table, the delusion was kept up, and he would consider Mr. Waterton a most successful game preserver.

Mr. A. Ellis imitated Mr. Waterton's plan, and tells us that on 1,400 acres he used to get six or eight brace of pheasants in a day. This admission seems sufficiently to condemn the system. They must have been nearly extinct before a gun was fired. Let anyone watch five pheasants feeding in a ten-acre field, and ask himself if a pheasant to every two acres is not the minimum 
one might expect. Then this 1,400 acres would produce 700 birds a year. If the farmer is protected a little at seed time, the breeding stock to produce this number will do him no harm. They would be his friends, for, as we have before quoted, 444 grubs of the crane fly were found in the crop of one pheasant; and with those pests, rabbits, ferreted down till they were only numerous enough to feed the foxes, and hares only plentiful enough to show sport with hounds and greyhounds, we should hear no more of the damage done by game to the crops.

But then, these fourfooted creatures are kept up to show sport by keepers who cannot show birds in sufficient numbers to swell the total to so many hundred head; and who really cares to pull trigger at a rabbit while the cock pheasants are sailing by fast and furiously in December? And what sportsman, asked to a day's rabbit shooting, which is excellent fun in its way, has not been pleased to hear that some 
166 GAME PRESERVERS AND BIRD PRESERVERS.

twenty brace of pheasants have unexpectedly been seen outside the covers? and he will not hurry on the less eagerly to try to stop them as he hears them beginning to rise at the end of the wood, whether he thinks they found their way there from Lord A.'s, who rears what are called tame pheasants, or from Mr. B.'s land, whose pheasants hatch their own eggs.

There are two classes who affect to despise pheasant shooting-those who know literally nothing about it, and those who know a little too much.

The first of these have probably never seen a pheasant shot. They visit some of our noblemen's beautiful 'show places' in August perhaps, and they see the keeper feeding hundreds of pheasants which come at his whistle. They fancy the same thing goes on in the shooting season, and that the sportsmen stand and fire into these flocks of birds promiscuously, and they write to the papers with this idea running in their heads. 
The second class are those who cannot hit them; and not to be able to shoot a tame pheasant is so provoking that they 'pooh-pooh' the whole thing; and they often also do not get asked to try, and that is more galling still. For one man who can drop a brace of pheasants where the trees are high and with the wind blowing a little, and take his spare gun from the loader and drop a brace more, there are three who cannot; and many men who have stood for big game in Indian jungles and acquitted themselves creditably and who shoot well over dogs, do not shine at this sport, though they hold their own pretty well.

But it is the gentlemen who pick their shots on the 'never miss' principle, who kill seven birds where one of the Hurlingham pigeon shooters would drop twenty-one (though he would certainly miss a certain number of shots in doing this), that the owner of the preserves least likes to see; and as he watches, on some occasion, bird after bird glide by into the ene- 
168 GAME PRESERYERS AND BIRD PRESERVERS.

mies' country, a little too far off, or going a little too fast to suit his friend, he makes a mental resolution to remember to forget to invite him next season.

The fact is, that tame-reared pheasants are exactly as difficult to shoot as wild-bred birds. Ours always joined the wild birds before November, and we never found any difference. It is the place where they have constantly fed in security, more than the person who feeds them, which gives them confidence; and the same birds which would still come to our feet in September if we called them at the spot where they were reared, could not be induced to come near us if we met them only four hundred yards off, 'whistled we never' so kindly.'

We are quite sure the pheasants never suspect the presence of their kind quiet friend the keeper, among the party of noisy demons who have invaded their stronghold. As it is their nature to do, they hide in the dense cover 
as long as possible, and, when obliged to take wing, fly as fast and far as possible ; and no wildbred pheasant can do more.

The reductio ad absurdum is generally possible. To shoot a stag is the height of many men's ambition. But to stand beside Queen Elizabeth and her ladies while with cross-bows they fired into herds driven close by, killing or wounding at every shot, would give few people any gratification.

When royal personages join in any sport, they are bound to try to excel other performances. Noblesse oblige. It would not be the thing to do less, and 'the fierce light which beats upon a throne' reveals all always. So pheasant shooting can be overdone, as when we read in the papers eleven hundred are shot in a few hours in France. But when six English gentlemen have bagged three hundred in some six hours, although it is a splendid bag, and it will require a cart and horse to carry it home (such a serious grievance with some people), 
170 GAME PRESERYERS AND BIRD PRESERVERS. it has not amounted to eight birds an hour for each gun, and they have no more done a cruel action than the parish clergyman and his friend, who, on the most successful 1st of September they ever remember, once bagged thirty brace of partridges. 


\section{CHAPTER XV.}

\section{PHEASANT REARING. ${ }^{1}$}

WHEx we know that with ordinary luck and good management six hen pheasants in confinement will produce at least one hundred birds, ${ }^{1}$ while these six hens left at liberty would probably produce about eighteen, one would expect that everyone who likes to see pheasants on their ground in autumn would keep at least this number; but the supposed difficulty of rearing them deters many, and the supposed great expense deters others. They need not cost more than the same number of chickens. We would not

1 The author has never seen Mr. Tegetmeier's work on Pheasants. These remarks are entirely the result of his own experience. 
172 GAME PRESERVERS AND BIRD PRESERVERS.

keep these pheasants in the little cages, twelve feet square, one often sees. Wire netting is cheap, and a sunny nook in an orchard, or a corner in a shrubbery, is easily enclosed, where they can have plenty of room; and they should be moved on to fresh ground two or three times a year. To visit these birds and bring them little delicacies is a constant amusement to ladies and children who are fond of live pets. They will eat anything poultry will eat, and the more their food is varied the better. When we have kept a cock to each three hens we have hatched eleven out of thirteen eggs, so we recommend this number. Others keep a cock to five hens. They will begin to lay in April, and will lay from twentyfive to fifty eggs a-piece. We never had a healthy hen that did not lay.

We were told one year that more than half of a hundred hens which were enclosed in twenty large pens had not laid at all. No doubt, these birds all ate their eggs. It is 
one of the very commonest and least suspected causes of failure, and no change of food will prevent their doing this if they once find out how nice new-laid eggs are.

It arises from curiosity, in the first instance. Introduce an egg into a pen where the birds have not begun to lay. They will nearly all peck at it a little, and turn it over and over. If it breaks, and they taste it, they will eat it shell and all to the last morsel ; ${ }^{\bullet}$ and shortly afterwards every egg will be watched for, and totally demolished, a damp mark on the ground being the only trace it will leave. These birds are ruined for that season at any rate. The cure is to have artificial china eggs made, and to put several in each pen a week or two before they begin to lay. They will peck at these at first; but pecking a slippery lump of china is so unsatisfactory an amusement that they soon take no notice of them.

They cannot tell the real eggs from these (no more can the man who collects the eggs, 
174 GAME PRESERVERS AND BIRD PRESERVERS. who will often pick them up by mistake), and they will not meddle with them experto crede. Another little matter, but yet a very important one, is that they should have plenty of old mortar or lime in the pens. If this is neglected the shells of their eggs will be so thin that the most careful hens will break twenty or twentyfive per cent. during incubation, while, when this is attended to, we have scarcely had one egg broken. •

Numbers of eggs are spoiled during incubation. An egg requires pure air as much as it needs heat. There is nothing more unpleasant than the smell of wild flowers round a pheasant's nest. It is the common custom to fit up an outbuilding with boxes, and fifty or sixty hens are set in these. Mr. Bailey advises that when they are taken off to feed they should be tied by the leg to a peg; then caught, untier, and put back.

This is better than letting them run twenty at a time in the outbuilding. Catching them and putting them on again is a scene of wild 
confusion, and the smell in these houses is most unpleasant. And many of these hens brought from a distance will sit for a few days, long enough to spoil the eggs, and then cease to sit, and it is almost impossible to detect that they are spoiling the egos until it is too late.

If we have fifty eggs or two thousand to hatch, there is one plan we adopt. Each hen requires a box with a lid, no bottom, and a sliding door at one end. This stands in a field near the keeper's house. The door opens into a coop made of laths, large enough for the hen to feed in. We put a sod of turf in the box to raise it a little from the ground, and a nest of very short hay on that. The damp from the ground is most beneficial to the eggs. They are then placed as the wild bird places hers. The hen is brought over-night and put on hen's eggs in the box. If she goes back of her own accord after coming off to feed next morning you may trust her that night with pheasant's eggs. 
176 GAME PRESERVERS AND BIRD PRESERVERS.

Every morning the keeper opens the lid. If the hen is wild she will walk off of herself; if not, he lifts her and puts her through into the coop, where she finds food, water, and dry earth. At the end of three quarters of an hour he has only to draw back each slide and each hen glides on of herself. A hen that does not go on willingly, or that comes off again, is on the strike. You detect her at once, and save the egg's. A double row of thirty boxes will hold sixty hens, which will hatch 1,000 eggs. A keeper will go down and put them all off in ten minutes; he can go about other things, and come and let them all on again in five minutes, when they have been off a clear three quarters of an hour. It takes a man a whole morning to feed these hens twenty at a time; and, again, a hen never breaks an egg if she walks on the nest, but often does so when struggling out of a man's hands. But do not let any novice forget to shut the door when he puts the hen off, and to keep her off for the proper 
time. In our absence once a man let the hens go back as soon as they had fed, and spoilt nearly every egg. Eggs must be thoroughly cooled each day.

Five hundred or a thousand pheasants reared by hand is a great success, but we are sure the expense is often double what it need be. We should like to know how many hen pheasants produced the eggs, and how many eggs were required to hatch these birds, before allowing that it was really well done. Keepers are not often inclined to go into these details, and they seldom put down on paper what eggs they use. This plan of out-door hatching may be adopted in many places, though we do not happen to have seen it, or to have heard it recommended. We do not think any who try it will go back to the old plan. We should mention that the sliding door is left open after the hens go on, on purpose to allow any hen who is getting tired of the work to show that she is so by coming off a second time; and they are watched as much. 
178 GAME PRESERVERS AND BIRD PRESERVERS.

as possible, and many a whole sitting of eggs is saved. Yet many men who should know better will keep putting on unwilling hens, thinking that if the licl of a box is shut, so that she cannot stand upright, she must sit and hatch the eggs, until some morning they find them scattered all about, and the mischief is done. And we shut the slides at night as a protection from rats, and to prevent any hen coming off before we feed them, as when they do this the eggs get cooled twice. We mention these little matters, because it is attention to these trifles which makes the difference between success and failure.

Hens will occasionally kill every chick as soon as it is hatched, so watch them with the first. We have had them kill pheasants and black grouse, and the only brood of red grouse we hatched were all killed but one. As no other hen was hatching on that day, we trusted him to a motherly old turkey who had just begun to sit, and she was very kind to him for two 
days. He was a brave little bird, and had no intention of dying if he could help it. We often took him out, and fed him on chopped eggs and young heather, and he would peck at it as we held it, and pull till he tumbled backwards, and then up and at it again. We put him after dark under a hen who was hatching pheasants; but in those two days he had learnt to love the old turkey, and he knew her gentle voice, and she missed the little creature and called to him; and he left his warm bed under the strange hen, clambered over the side of a high basket, and ventured in the cold and darkness all across the building to her box, but he could not get in, and was lying dead close to it in the morning, and we were sorry for him.

The young pheasants must be put out the day after they are hatched. Coops are cheaply made, and we use two for each hen, putting the empty one a few inches in front of the other in wet and stormy weather. It prevents 
$1 S 0$ GAME PRESERVERS AND BIRD PRESERTERS.

it being blown over, and the birds feed without getting clilled. In fine weather it is drawn back three feet, but for the first two or three days close-fitting boards must join these coops, or the newly hatched pheasants will stray away and be lost.

Plenty of keepers can rear nearly every bird, but there is generally a mystery kept up about it. If ants' eggs can be procured they are easily reared; but ladies and children do not attempt it, as they fancy it is necessary to feed them at daylight. We have constantly proved this to be quite needless. We put down their breakfast the last thing at night in the empty coop. They find this when they wake hungry soon after daylight, and are ready for a second meal at eight o'clock. We allow each twenty-five birds an average of six hardboiled eggs a day, mixing them every week with Indian meal, oatmeal, and boiled rice in larger proportions, and giving ants' eggs after each meal. If milk is plentiful the eggs will 
go much farther if made into custard. When six weeks old they will do well enough without the eggs; and, managed in this way, we know two children, aged eleven and nine, who can rear forty or fifty pheasants without any assistance. Ants' eggs are best collected in a zinc bucket with a close-fitting lid, and this should be filled with water for a good many hours before they are given to the birds, or the ants will sting them so about the legs and eyes that they will be afraid to come near them. In August they will find their way into the corn-fields; and, if they get good picking on the stubbles, perhaps boiled potatoes and raisins are as good things as you can put down to keep them near home. When reared in small numbers of 150 or so, they will be found to do better if put in separate lots of not more than fifty together.

Birds of the same age being together the smaller ones do not get robbed by the older birds, and they all catch so many more insects 
182 GAME PRESERVERS AND BIRD PRESERTERS.

when in different fields, or different corners of a large field.

You will see but little of them after September, and in the brilliant cock pheasant who comes straight at you on a winter's day, at the rate of a thousand miles an hour, crowing defiance all the time, you will no more recognise the brown bright-eyed little bird which used to feed at your feet, than he will recognise in you, as you so wickedly try to stop him with both barrels, the amiable biped who used to throw him ants' eggs in the summer mornings.

And whether you succeed, and he finds his way to your friends' tables, or you fail, and he fincls his way to your neighbours' woods, perhaps to have another year of happy life, the game has been fairly played out between you. Some writers seem to wish pheasants were exterminated. We think that the more which are reared in England the better for those who like to see them, those who like to shoot them, and those who like to eat them; and most of 
the people we know belong to one or the other: of these classes. And surely the more that are hatched the better for the pheasants themselves. Whether a pheasant lives six months. or six years there exists no happier bird. Can it be ignorance of the natural history of foxes and pheasants which makes so clever a writer. as Mr. Hughes advocate their extermination, in advocating the abolition of field sports? And he does this, he states, on the grounds of humanity on account of what they sometimes. suffer when hunted or shot. 'Save us from our, friends!' must be these creatures' cry. He would act more logically, we think, if he advocated the extermination of the human race on account of what so many suffer when they die of such diseases as ' cholera.'

And he has another reason-'So many men are imprisoned because they steal pheasants.' But, as has been often observed in answer to this argument, we do not close our butchers' shops lest the hungry hundreds in our towns should be 
184 GAME PRESERVERS AND BIRD PRESERVERS. induced to steal their contents; and when sheepstealing was common, it was not suggested that the proper cure was for farmers to cease to keep sheep. Would not Mr. Hughes do more to elevate the moral standard of his listeners when he is lecturing the working classes, if he taught them to admire our beautiful pheasants, instead of almost insinuating that if landowners will encourage these birds they can hardly be supposed to resist the temptation of carrying them off at night and selling them to some unprincipled poulterer for half their real value? 


\section{CHAPTER XVI.}

THE WOOD-PIGEON AND HOUSE-SPARROW.

The wood-pigeon and the house-sparrow, two birds differing in their habits as widely as possible, are the only two birds whose numbers it would seem desirable to reduce. The firstnamed bird is, except, we think, by one or two witnesses, universally condemned; but several find plenty to say in defence of the bold little sparrow.

Few people have any idea how enormously the wood-pigeon has increased in numbers in the last thirty years. Mr. Scott Skirving, a gentleman who farms 800 acres of land in the East Lothians, gives a great deal of information about them, and his figures are quite astounding. He tells the Committee: "Forty 
or fifty years ago they were very scarce; if you saw one it was a wonder. Now at almost every season of the year there are flocks of wood-pigeons in the East Lothians and the adjoining counties. I would estimate a flock at about 20,000 in number. They do an enormous amount of evil. They are entirely graminivorous and vegetable-feeding. When there is a snowstorm they eat the whole of the tops of the turnips, and leave them exposed to the frost; but in the spring they do the most damage. They fill their crops twice a day with the clover plant, packing it as large as a cricket ball. Then when the turnips are singled they pull them out, and when the corn is ripening they settle in the fields in flocks, and trample it down with their weight. We have an association for killing them, and pay for about 25,000 in East Lothian; but that is a mere fraction of what is killed. They sell for $6 d$. each. They are very good food.'

Mr. Scott Skirving attributes their increase 
THE WOOD-PIGEON AND HOUSE-SPARROW. 187

principally to the improved cultivation of the farms. 'Formerly there was no food for the wood-pigeon in the winter time; but when the red clover became common it gave them food, as did the turnip-top, all the year round. I have no doubt we get large importations of these birds from the centre of Germany, and they never go back.'

He also attributes it to the decrease of birds of prey; but no numbers of these could now make any sensible impression on such countless hosts. And he states: "One hard winter I had a field of rape, and I allowed everyone to shoot them who could, and I have counted 12,000 birds in one week, and yet they ate the whole of the crop; none of it was saved.'

We wish the size of this field had been stated. At $6 d$. each, these birds were worth $300 l$., which would be some slight compensation for the loss.

But even the wood-pigeon has one friend: Mr. John Cordeaux, who farms 700 acres in 
$1 S S$ GAME PRESERVERS AND BIRD PRESERVERS.

North Lincolnshire, would not like it destroyed, 'on account of the enormous amount of noxious seeds it picks up;' and he mentions the names of many weeds whose seeds he has found in its crop. The Rev. Mr. Morris believes large numbers come to Scotland from the north of Europe, and that it does some good. But surely the fact that a change in our system of cultivation should have caused such an enormous increase in the numbers of such a beautiful bird opens a wide field for reflection. We must be very far off from knowing at present in what numbers many other birds would exist if. we understood and attended to their wants in winter. For now, ' every five or six miles throughout the country you come on a flock of 10,000 wood-pigeons, where thirty years ago they were quite rare.'

The farmers in the East Lothians are quite right to put a price upon its eggs; it is spreading in all directions. Mr. R. Gray 
THE WOOD-PIGEON AND HOUSE-SPARROW. 189

says: 'It is totally unknown in the Western Hebrides.' We have repeatedly shot it lately in the extreme west of Argyllshire.

The house-sparrow is so clearly, as the Rev. Mr. Tristram describes him, like the rat, a parasite on man, that no ordinary rules apply to him. His motto may be said to be-

De l'audace, encore de l'audace, toujours de l'audace.

$\mathrm{He}$ robs the wild beasts of their food in the Zoological Gardens, the poor man's pig and the rich man's pheasants. He will not starve while we have a fowl alive, nor die of cold while there is a warm hayrick in the country. The cat is perhaps his only dangerous enemy, and she makes no impression on his numbers.

$\mathrm{He}$ is about the last bird the so-called sparrow-hawk is likely to kill often, as he keeps so near our houses. If his numbers are to be reduced, man must reduce them himself; but whether he ought to do this is quite a vexed question. 
190 GAME PRESERVERS AND BIRD PRESERVERS.

We can only quote some of the arguments advanced for and against him. Opinions seem pretty evenly balanced.

We believe he drives away other birds, such as the chaffinch and yellowhammer. Netting them in winter is quite a legitimate way of destroying them, and if they are shot from a trap next morning they will have a chance to escape. A lad of sixteen who can stop nine out of twelve at twenty yards' rise will be able to handle a gun to some purpose when he goes out to our colonies; and all boys cannot have game to practise at.

Mr. Champion Russell hates the sparrow. - Their crops are full of barley and oats, except when they can get wheat. Then they attack the green peas in pod. But the chief mischief is eating the green wheat when it is pulpy. The juice runs out of their mouths like milk when they are shot. A farmer often loses $20 l$. on a field by them.' This is rather strong evidence; yet the very next witness, $\mathrm{Mr}$. $\mathrm{H}$. 
THE WOOD-PIGEON AND HOUSE-SPARROW. 191

Meyers, 'would like to see them increase tenfold.' He exterminated them once, but blight of various kinds increased so that he was glad to get them back. And this evidence is borne out by Mr. Harting, who tells us that at Baden a price was put on their heads, and that then the cockchafers increased so that they were reintroduced at some expense.' Under one sparrow's nest 1,400 wing-cases of cockchafers were collected and counted, yet the stomachs of young sparrows are constantly full of wheat and peas. Mr. Groome Napier thinks they do more harm than good. One hundred stomachs of young sparrows were exhibited in 1865, and there was not five per cent. which contained insect food.

Mr. Lewis Fytche thinks him most useful, and Mr. Cordeaux that 'the good he does overbalances the evil;' but he takes their nests as they turn out other birds.

Mr. C. Russell thinks ' nearly all evidence in favour of sparrows is founded on partial ob- 
192 GAME PRESERVERS AND BIRD PRESERVERS.

servation, or is vitiated by the fact that, when they are killed down, other birds are also exterminated.' No doubt this is often true; and we would take care to protect plenty of other birds, which are more strictly insectivorous, before destroying them. Capital punishment should be inflicted by man alone. He destroys so much more mercifully than when creatures destroy each other.

They soon get used to the report of a gun, and they will even sit in a tree and continue to feed while some of their number are being shot. But the sight of a hawk fills them with terror from which they do not recover for a long time.

Although the sparrow has followed the Russians in their advance into Siberia, he has not yet established himself in the rest of Argyllshire. His place round our farms is supplied by a little cloud of chaffinches. 


\section{CHAPTER XVII.}

\section{HOW TO PRESERVE ALI BIRDS.}

ALL birds require three things: protection during their breeding season, a home that suits them, and to be able to procure sufficient food in winter. If man chooses to provide them with these blessings, probably the numbers of most of our birds, from the tomtit to the black-cock, might be increased to almost any extent.

We protect them by destroying, with the help of our gamekeepers, or rather birdkeepers, the following birds, which destroy them on every day in the year, or their eggs and young whenever they can find them: the falcon, the buzzard, the hen-harrier, the sparrow-hawk, the merlin, the raven, the crow, the magpie, 
194. GAME PRESERVERS AND BIRD PRESERVERS.

and the jay; while the kestrel and the owl are under surveillance never to be destroyed unless detected flagrante delicto.

Will any reader who has had the patience to follow us so far, compare this list with the statements made before the Committee and quoted in the second chapter, that gamekeepers destroy every bird which is not in the Game List?

And one gentleman states that keepers destroy 'our principal wild birds and animals.'

Are these murderers and cannibals our principal and most valuable wild birds?

But some writers are never tired of atttacking and misrepresenting field sports and all connected with them. One gentleman last winter could find no adjective strong enough to express in one of the newspapers what he thought of anyone who shot more than a certain number of pheasants in a day, and he boasted that he was proof against all arguments. We do think if he could live for a couple of years as a 
blackbird he might alter his opinions. The first year he shall live in the park of a game preserver. Here he will enjoy perfect happiness. He can warble his sweetest songs and rear his family in peace, and will know no anxiety except to take care to wake sufficiently early to secure the early-rising worm. The following year he shall live in the pleasuregrounds of a gentleman who is so fond of birds that he has written a book about them, but who thinks it wrong to interfere with the balance of Nature. Here he will see his first. wife killed by a sparrow-hawk, and his second carried off by a merlin on the day on which she laid her first egg, while three out of the four young ones he rears by his third will be killed by a cat as soon as they leave the nest; and on some occasion he will only save his own life from the same creature by the sacrifice of his tail. We do think he would begin to realise who were birds' friends, and afterwards, 
instead of writing these letters, we should see his name in the advertisement column of the same newspaper as the inventor of a patent cat trap.

And we also kill the mountain fox, the wild, or vagrant, wandering homeless cat, the polecat, stoat, and weasel, and the rat and the hedgehog; and when none of these creatures infest our mountains, woods, and fields we know that our beautiful and useful wild birds can breed in peace.

A home that suits birds is not always easily procured, and here Mr. Waterton was far in advance of his age. His protection of the poor persecuted water-fowl was worthy of all imitation. We are sorry for these birds, which must recede before man. The command, 'Let the dry land appear,' which suits him so well, is their destruction.

But he need not hunt them off every bit of water on which they are ever seen. If he would systematically protect them he would be 
well repaid. There is not a pond of half-anacre in extent which would not always hold ducks if kept quiet, and if a little shelter was provided. A screen of bitter osiers would sometimes make all the difference, or a belt of larch trees, shutting out the view of some public path. On some fine pieces of water wild fowl of various sorts breed every year, and their young are taken as soon as hatched, to the last bird, by large pike which are far too cunning to take any bait, and which often cannot be netted on account of the weeds.

This is a serious evil. We offer the following suggestion for what it is worth, not having tried it. We would hatch some ducks early in the year, and before putting them on the water we would sew up in a bit of waterproof and fasten on the back of each securely with some elastic, strychnine enough to kill a man. As these packets should not be labelled poison, the pike would probably not notice them, and perhaps Mr. Buckland could tell us 
198 GAME PRESERVERS AND BIRD PRESERVERS.

if they would be likely to require any more ducks out of our next brood.

Mr. Waterton set also an admirable example in providing house accommodation for many sorts of birds, which have great trouble in finding suitable habitations. He may be said to have originated the plan of making model lodging-houses for owls, starlings, \&c. \&c.

He is imitated by Mr. A. Ellis, who states that he fitted up chambers artificially in the hole of a hollow elm-tree, and that a kestrel, a stockdove, and two pairs of starlings all hatched off their young in this one chamber. Surely this old tree must be an interesting object to anyone fond of natural history.

The Rev. Mr. Morris saw at Walton Hall another hollow tree in which a pair of owls, a pair of jackdaws, and a pair of redstarts bred, and all these birds entered by one hole. We should like to see these model lodging-houses common on every estate. They would soon find tenants, for old and useless trees are so 
generally cut down now, that all the birds which like to build in holes are at their wits' ends to know where to go.

Perhaps one of the most useful birds in the world, the starling, has increased more than almost any bird. He is now common in the west of Argyllshire, where he was unknown, and he has great difficulty in finding holes to build in.

The necessity of finding nesting accommodation for birds is noticed by Mr. Muller. Our system of cultivation finds home and food for an ever-increasing host of insects, but the birds which would live upon them are driven away by the destruction, in so many places, of all the trees and hedgerows. The useless old hedgerows will never return, but we do think a system of planting occasional strips will be adopted. These would be screens from certain winds, a cover for pheasants, and a secure hiding-place for our insect-destroying friends; and thinnings of these, if planted with such 
200 GAME PRESERVERS AND BIRD PRESERVERS.

trees as the larch, would make some return in value for the ground they would occupy. They would wonderfully improve the appearance of the country. Immense tracts of land without a tree or bush, however carefully cultivated, are not our idea of an English landscape.

But protect and plant for our birds as we will, without food in winter they will never become very numerous. They get through a mild winter pretty well, but in a severe winter ' they die by millions.' Perhaps nine-tenths of the blackbirds and thrushes die. After one severe winter, Mr. J. Eccarius noticed that these birds and the robin had become nearly extinct.

And we let them die at our very doors of hunger, and except to the poor little robin who will come and ask our children to pity and feed him sometimes, we never throw them a scrap.

Poor little creatures! They must find their Sorrows, crown of sorrows, in remembering happier things. 
Can this world, with its iron-bound icy covering and its few short hours of daylight, be the same place which they remember where they found delicious food at every step, and where the long summer day was not long enough to sing of all their happiness in?

They could bear the cold but not the hunger in addition. So some evening, feeling fainter than usual, they creep into some little sheltered corner and die. Every garden should have its table for the birds in winter, and children take a delight in watching them come each morning for their daily meal. All the birds that stay the winter with us can be kept alive with such a little help from man.

The cheapest rice, a little Indian meal, and a few pounds of suet or liver chopped up occasionally in hard weather, will save the lives of scores, and it is only thoughtlessness which prevents these things being supplied, for but few living in the country would grudge the expense. 
202 GAME PRESERVERS AND BIRD PRESERVERS.

We should like to see insect-eating and weed-destroying birds swarming in our gardens and fields, and wild-fowl breeding in peace on every pond; and as we are now largely importing very inferior game birds for food, we think our modern naturalists would do us better service if they would tell us how to make our grouse, pheasants, and partridges ten times as numerous as they are, so that they might be common on most men's tables instead of constantly advising us to feed other birds and beasts with the flesh and eggs of the ferv we still possess.

If edible birds are to be eaten they must be killed, and this leads us to the question of what is the most merciful way to kill them. We have no hesitation in saying that the most merciful way is to shoot them. Most of them die in the air and never know what hurts them, while the few wounded are the exception which proves the rule. Numbers of people if they heard that a gentleman had had his woods surrounded with 
nets and the pheasants all driven into them to struggle screaming with terror until their turn came to have their necks broken, would think he had acted with great humanity, while we are sure that our very tamest pheasants suffer more when caught occasionally to have their wings cut than if they were shot. The mere handling a wild bird causes terror, and we used even to have our guinea-fowls shot in preference to hunting and catching them.

Many ladies rear numbers of turkeys and chickens, and though it is well known that their superfluous stock are killed and some of them sold, no one thinks of accusing these ladies of cruelty. Yet it is a far more miserable thing to watch a poor turkey tied up by the legs bleeding to death than to see a hundred birds shot flying. And the wounded even do not suffer as some suppose. Let anyone observe the expression in a bird's eye as his retriever brings him, carrying him 'tenderly as though he loved him,' as Sir Isaac Walton advised his disciples 
to handle the young frog they were about to impale on their hook. It is much more intense astonishment than agony which it expresses. The shock seems to have stunned its faculties. It says plainly, 'Where am I? what has hap. pened?' And a tap on the head ends its sufferings.

As birds cannot extract the shot, those hit in the body must die soon or perfectly recover.

We remember once seeing a bad shot apparently miss two cock pheasants, which we marked into a little patch of gorse. On going to beat them out they were both picked up dead.

Then sportsmen are directly accused of finding pleasure in inflicting pain and suffering. So, if it could be revealed to us that birds do not suffer at all when shot, but in a happy ecstasy pass to another existence (and if, as an American poet, writes-

All that we see or seem

Is but a dream within a dream, 
for the sake of the argument we can imagine this), should we cease to pursue them, or should we find no pleasure in shooting them?

Does anyone honestly believe for a moment that this would be the case?

But, on the other hand, if guns could be so improved as to certainly kill or wound every bird we shot at, we are perfectly certain that their destruction would lose all interest, and but few would ever follow them.

It is the exhibition of skill and the achieving what is difficult which gives the charm to shooting, and we find an additional charm when the pursuit of game leads us to wander for days among the most beautiful scenes in nature, and taxes our physical powers to the uttermost.

It is one of the healthiest signs of the age that as wealth and luxury increase, and with these the possibility of leading a life of perfect ease and indolence, in the Anglo-Saxon race a love of all manly exercises seems to increase in 
206 GANE PRESERIERS AND BIRD PRESERVERS.

an equal proportion. Among Orientals you can often tell a man's income by his weight. As soon as he can afford to sit still he seldom takes any exercise. One of the Eastern princes, on being taken to Almack's, could not understand why we did not make our servants do the dancing while we looked at them.

There is not an enterprising manufacturer in England who has amassed a large fortune who may not feel sure, however little he may happen to care for rod and gun himself, but that some of his descendants will be spending the splendid means he will leave at their disposal in ransacking every corner of the known globe in pursuit of sport.

Pigeon-shooting is considered the most cruel form of shooting, but even here people make a mistake. Possibly no such blessing could have been invented for the pigeons as the revival of this sport, as they are now breeding in happy hundreds where but few used to exist, 
for it did not pay to keep them only to find their way into pies.

But it is so ridiculously easy to shoot a tame pigeon. So different from killing a wild mountain grouse! In very remote parts of Scotland where grouse have never been shot at, we have occasionally found them as tame as the boobies which the sailors knock on the head in the South Sea Islands. On three different occasions we remember throwing our hats at grouse to make them fly as they persisted in running, scolding, and chattering, and jerking their wings and tails in their most impertinent manner under our feet and under the dogs' noses, and these were all full-grown, strong birds. Young squeakers always lie hid until almost trodden on and then fly as far as they can. One of these parties of unsophisticated grouse so scandalised a very excellent dog who found them at some distance from us, that we saw him get up, turn tail, and slink away, and 
208 GAME PRESERVERS AND BIRD PRESERVERS.

take up his point again fifty yards off, waiting for us to come and advise him how to act under such unusual circumstances. Which was the easy bird to shoot? One of these grouse, or the tame pigeon, which is out of the trap you least expect, and you verily believe before the string was pulled, and is away with a dash and twist which an Irish snipe might envy; and, though you have the best gun in England in your hand, and though you would go home a richer man by $500 l$. if you could, you simply cannot shoot him?

Rightly understood and properly carried out, men's dominion over the beasts of the field and the fowls of the air may be called a new dispensation for them, and it is an infinitely more merciful one than the original state of things under which they suffer and struggle for existence, while allowed to destroy each other on every day in the year.

When he refuses to interfere with 'the balance of Nature,' man wraps his talent in a 
napkin, and live creatures benefit but little by his appearance upon this earth, and he derives but little profit from them. It is greatly to be regretted, both for the sake of the birds and for. mankind's own sake, that every man, in whatever part of the world he may dwell, should not be a bird preserver, and consequently a game preserver. 


2 


U. C. BERKELEY LIBRARIES

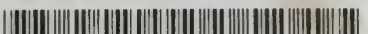

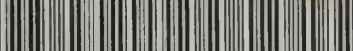

||||||||||||||||||||||||||||||||||||||||||||||||||||||||

C045833436 


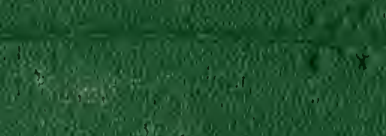

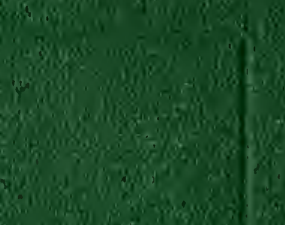

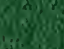

1.8.

3. 